Portland State University

PDXScholar

1978

\title{
"Fallen angels" : an historical review of program development and clientele of the Salvation Army White Shield Home with an emphasis on the years 1940-1976
}

Wendy Jo Ballard

Portland State University

Follow this and additional works at: https://pdxscholar.library.pdx.edu/open_access_etds

Part of the Family, Life Course, and Society Commons, and the Social Work Commons Let us know how access to this document benefits you.

\section{Recommended Citation}

Ballard, Wendy Jo, "'Fallen angels" : an historical review of program development and clientele of the Salvation Army White Shield Home with an emphasis on the years 1940-1976" (1978). Dissertations and Theses. Paper 2754.

https://doi.org/10.15760/etd.2746

This Thesis is brought to you for free and open access. It has been accepted for inclusion in Dissertations and Theses by an authorized administrator of PDXScholar. Please contact us if we can make this document more accessible: pdxscholar@pdx.edu. 
"FALLEN ANGELS": AN HISTORICAL REVIEW OF PROGRAM DEVELOPMENT AND CLIENTELE OF THE SALVATION

ARMY WHITE SHIELD HOME WITH AN

EMPHASIS ON THE YEARS

$1940-1976$

by

WENDY JO BALLARD

A practicum submitted in partial fulfillment of the requirements for the degree of

MASTER OF SOCIAL WORK

Portland State University 1978 


\section{PREFACE}

The term "fallen angel" originates from the Bible. When Lucifer sinned, he was cast from heaven and is referred to as a "fallen angel" in biblical literature. In the early beginnings of the Salvation Army help was extended to the prostitute on the street. Because these women had sinned, and in that sense had "fallen," the term "fallen angel" was applied to them. Records of White Shield Home from the early 1900's refer to the unwed mother that was served as a "fallen angel." Brewers Dictionary of Phrase and Fables defines "fallen angel" in this männer: "those cast out of Heaven; colloquially, women who have slipped from the paths of virtue." (New York: Harper and Row, 1959, p. 396). 


\section{ACKNOWLEDGMENTS}

Special thanks to The Salvation Army White Shield Home Staff; Tricia Walsh, typist; my family, friends and colleagues. 
TABLE OF CONTENTS

PAGE

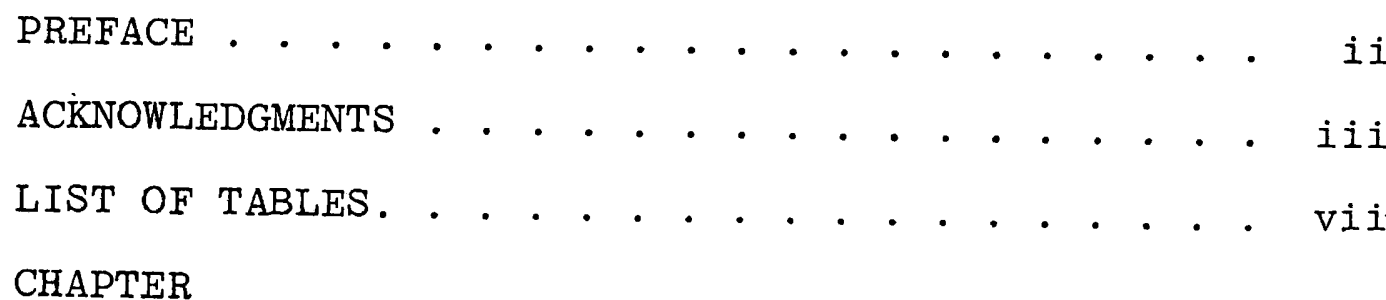

I INTRODUCTION. . . . . . . . . . . . . . 1

I I DESCRIPTION--SALVATION ARMY WHITE

SHIELD HOME OF PORTLAND, OREGON . . . . 4

Programs. . . . . . . . . . . . . 4

Residential Programs

Prenatal and Transitional Prenatal Program

Infant-Maternal and Transitional

Infant-Maternal Program

Hospital-Medical Program

School Programs

Infant and Toddler Child Care Center

Administration. . . . . . . . . 10

Social Services . . . . . . . . . . . 11

Food Services . . . . . . . . . . . 12

Chapel and Religious Services . . . . 12

Recreational Services. . . . . . 13

Girls' Council. . . . . . . . . . . 13

II I EARLY HISTORY AND BEGINNING OF THE

PORTLAND WHITE SHIELD HOME. . . . . . . 14 
CHAPTER

PAGE

IV THE CHANGING INSTITUTION . . . . . . 20

The 1940 's . . . . . . . . . . . . 20

The $1950^{\prime} \mathrm{s}$. . $^{\circ}$. . . . . . . . . . 27

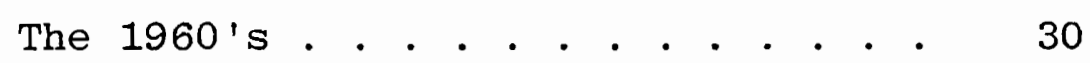

The 1970 's . . . . . . . . . . . 39

V HIGHIIGHTS AND SUMMARY IN TRENDS • . • 54

VI CONCLUSIONS . • . . . . . . . . . . . . . . 62

SOURCES CITED. • • • • • • • • • • • • • • • • • • . 65

APPENDICES • . • . . . . . . . . . . . . . . . 68

A The Wemme Trust. . . . . . . . . . 69

B Outline to Define Agency Function--

Child Caring Agencies. . . . . .

73

C The Salvation Army Policy on Non-discrimination . . . . . . . 78

D Notes on Salvation Army Facilities Tour . . . . . . . . . . . 79.

E Comparative Statistics-Ten Year Period $(1954-1963)$. . . . . . . 83

F Tri-County Community Council - Report of the Unwed Mother Study Committee.

G Letter - Description of Programs at White Shield Home-1972. . . . . . 96

H Report on Services at White Shield

Home and Wemme Maternity HospitalJuly 14, 1973. . . . . . . . .

I The Management Team Approach-1973. . . 102 
$\mathrm{J}$ Age Distribution By Decade. . . . . 103

K Percentages From Single-Parent

Homes By Decade . . . . . . . . . . . 104

L Percentages Receiving State Aid

By Decade . . . . . . . . . . 105 


\section{LIST OF TABLES}

TABLE

PAGE

I Comparative Data, 1944-1945 . . . . . . 26

II Age Distribution, 1945-1954 . . . . . . 28

II Circumstances for Non-admittance, 1965. . 38

IV Occupancy Rates . . . . . . . . . . 40

V Statistical Analysis, 1973...... . . .50,51 


\section{$22^{40^{53}}$}

CHAPTER I

INTRODUCTION

The following paper is a study of the history of the Salvation Army White Shield Home of Portland, Oregon with emphasis on the years 1940 through 1976. The White Shield Home is a residential program which provides comprehensive services to school-age parents. A complete description of $r$

the setting and the services offered is found in Chapter II. "School-age parents" is the current term used to refer to. unmarried pregnant women and women with infants in an effort to eliminate the stigma attached to "unwed mother" or "pregnant teenager".

The purpose of the study is threefold: 1) to familiarize the reader with trends that ocurred within the White Shield Home in regard to both agency and client, and allow the reader an appreciation of the various aspects of the Home; 2) to enhance the reader's awareness of the services provided by the Home and how each service came to be, in an effort to suggest the value of the Home to Portland and surrounding areas; and 3 ) to provide the basis for further study of White Shield Home.

Several methods were used in this study. A random sample of case records was taken for each ten year period 
from 1940 through 1975 to determine trends in regard to the client served by the Salvation Army White Shield Home. Due to the volume of information included in case records, the sample was quite small and inadequate for statistical purposes; however, certain observations from the results will be presented in this paper.

The population of White Shield consists of unmarried pregnant women and women with infants. A case record includes agency forms, social summaries, medical reports, referral information, etc. The sample was randomly drawn from index cards alphabetically ordered. The variables considered from the sample included age, race, and occupation of clients; percentage of clients from single parent homes; percentage of infants released for adoption; agencies used for adoption; percentage of clients using state aid; length of stay at the Home; acknowledgement of paternity by the alleged father; age, race, and occupation of the alleged father.

A second major method used to determine trends within the agency was an examination of the Hospital Advisory Board Meeting Minutes from 1957 through 1975. A study of these minutes reflects issues that portray similar trends in the White Shield Home and in the community at large.

Some issues in this paper may appear trivial to the reader. However, each issue presented reveals interests and concerns of the Hospital Advisory Council Board and in 
that respect had some influence on the course of action that the board of White Shield chose to take.

A survey of pamphlets on history, print-outs on rules, miscellaneous files, yearly reports of services, reports of completed studies, and interviews with staff members were included as methods in this study.

Excluded from this study is a detailed picture of the financial aspect of the agency. Concerns about finances are brought out at certain points but specific figures are not included. 
CHAPTER II

DESCRIPTION--SALVATION ARMY WHITE SHIELD

HOME CF PORTLAND, OREGON

\section{Programs}

The Salvation Army White Shield Home provides five general areas of service primarily for school-age parents.

These areas include: 1) a Prenatal Residential Program with a Transitional Prenatal Program; 2) an Infant-Maternal Residential Program with a Transitional Infant-Maternal Program;

3) a Hospital-Medical program; 4) a school program; and

5) an Infant and Toddler Child Care Center.

\section{Residential programs}

The residence is a two story dorm-like building occupied by women, ages ranging from twelve to twenty-five with an occasional woman over twenty-five. Each floor of the residence has a living space with lounging furniture, a television, and a kitchenette.

The residential staff consists of a Residential Manager, five full time Residential Child Care Workers and one part time Residential Child Care Worker.

The Residential Child Care Worker is on duty twentyfour hours a day. It is the duty of these workers to see that group living is carried on in an orderly manner and to 
deal with any emergencies that may arise. A residential worker provides a great deal of informal counseling, nurturing and mothering activities, and role modeling. Residential workers work closely with the White Shield social workers in providing consistent and appropriate services to clients.

Prenatal and Transitional Prenatat-Programs. On the second floor, there are seven 4-bed rooms and two 2-bed rooms with a total capacity for thirty-two pregnant women. Each room is equipped with closet and drawer space for full occupancy. Each room also has a bathroom.

Classes in the LaMaze method of natural childbirth are offered to residents of the second floor. Each girl is encouraged to attend these classes the last two months before her expected delivery date. Questions the girls have in regard to preparation for childbirth, childbirth itself, biological body changes, emotional experiences, breastfeeding, nutrition, etc., are also discussed. Films of actual childbirth experiences are shown.

White Shield also offers what is called a Transitional Prenatal Program which allows a girl who has decided to release her child for adoption to temporarily reside in a space on the second floor while she is adjusting to her decision or until she makes further living arrangements. 


\section{Infant-Maternal and Transitional Infant-Maternal}

Programs. The first floor of the residence is occupied by single mothers and their children. In this program, mothers pursue long-term educational or vocational goals.

There are seven 2-bed, 2-crib rooms and two 1-bed, 1-crib rooms allowing for a capacity of sixteen mothers with babies. Each room has a bathroom and is equipped with a changing table for each infant, diaper pails, closet and drawer space for full occupancy.

White Shield offers a Transitional Infant-Maternal Program also. A girl may temporarily reside in a space on the first floor after she delivers her child to allow herself time to adjust to having a child or until plans for further living arrangements can be made.

Hospital-Medical Program

A Hospital-Medical Program is provided for the girls in the prenatal program. A hospital, funded by the E. Henry Wemme Endowment Fund, is located in the administration building on campus. A bi-weekly prenatal clinic is held at this hospital. By contractual agreement, White Shield girls deliver at University Hospital North. In exchange, some University Hospital North prenatal patients who need extended bed rest are placed in White Shield Hospital. At White Shield a 4-bed ward is set aside for this purpose. 
At White Shield Hospital there are two rooms each containing space for two White Shield "rooming-in" patients, a 4-bed recovery ward reserved for White Shield girls who have released their children for adoption, and a 2-bed ward for White Shield women while in labor.

The White Shield Hospital staff consists of a Health Coordinator, two full time registered nurses, and seven part time registered nurses.

A prenatal clinic is held at White Shield Hospital on Mondays and Thursdays. By appointment girls are weighed, measured, and examined. Girls are seen in clinic more often in their third trimester of pregnancy. A nurse/midwife examines the girls in clinic, follows each girl through delivery, and provides postnatal care. A doctor at University Hospital North is on call at all times in case of any complications during pregnancy or delivery. Student nurses from the University Health Sciences Center are assigned to each girl and also follow her pregnancy, usually coaching her through delivery.

When a girl begins labor, she sees a Residential Child Care Worker who escorts her to White Shield Hospital. The nurse on duty examines the patient and admits her for observation. When the nurse feels the girl is close to delivery, she sends the girl to University Hospital North in a chair car. If there are no complications in delivery the girl will return to White Shield in twenty-four hours to complete her 
hospital stay, usually five to six days. During this time, nursels teach girls baby care (i.e., bathing, temperaturetaking, feeding, formula or breast preparation). The girl is then released to either the Infant-Maternal Program, the Translitional Infant-Maternal Program, the Transitional Prenatal| Program, or to a home in the community. A postnatal check-up is required four weeks after delivery.

White Shield Hospital provides vitamins and other necessary medication to prenatal girls.

\section{School Program}

White Shield Home School is financed through the Portland Public School District under the provision that education must be made available to any person under age twenty-one. The school offers grades seven through twelve, a General Education Degree (GED) program, and vocational classes and counseling.

The staff of the school is made up of one full time head teacher, one half time teacher, three full time teachers and a half time secretary. The head teacher is in charge of administration of the school and teaches Parenting Classes. The half time teacher is a Learning. Disability Specialist and teaches students who have a lower than seventh grade ability. The other three full time teachers teach subjects such as Math, English, Social Studies, Science, Physical Education, Personal Finance, Business and Home Economics. 
When a girl enters the Home she is given the Comprehensive Test of Basic Skills which determines her grade level and deficiencies, if any, by her scores in Reading, Language, and Math. In order to set up the optimal program for each student, the head teacher obtains records from prior schools to help assess the student's status in terms of grade level, credits already obtained toward graduation, and any other relevant information. White Shield Home holds a graduation ceremony at the end of every school year and students who have completed their credits may participate in the ceremony.

White Shield teachers work closely with White Shield social workers in order to provide optimal, consistent services to the residents.

\section{Infant and Toddler Child Care Center}

The White Shield Infant and Toddler Child Care Center admits children of mothers in the Infant-Maternal Program as well as children of single parents from the community. Children from six weeks old to three years are admitted for child care. The capacity of the center is twenty-four. Ten spaces are reserved for White Shield residents and the other fourteen spaces are for community use. The Child Care Center has two main funding sources; the State of Oregon Childrens Services Division currently pays for each child from the community, and the Salvation Army pays for the children of mothers from the Infant-Maternal Program. 
The children are divided into three groups in order to give the appropriate and optimal stimulation according to age. The groups are: 1) infant; 2) transition; and 3) toddler. The transition group is made up of the oldest infants and the youngest toddlers. These are children who are becoming independent. and beginning to walk. They need to be separated from the infants because they are physi: cally and mentally more advanced and they need to be separated from the toddlers because they are somewhat behind them in development.

The staff at the Child Care Center consists of a Director, an Assistant Director, five full time teachers, and one part time teacher.

White Shield Home Child Care Center is highly structured and places a great deal of significance on child development and relationship-building between parent and child.

\section{Administration}

The Administrator of White Shield Home is an officer of the Salvation Army and is directly responsible to the Salvation Army Headquarters in Los Angeles. Colonel Vivian Johnson is presently the Director of Womens and Childrens Services of the Western States and is the officer to whom the White Shield Administrator is directly responsible. A11 other administrative staff members are employed by the Salvation Army and include a full time Program Coordinator, a 
full time bookkeeper, a full time statistician, two full time receptionists and a part time secretary. The Administrator and the Program Coordinator are the only two members of the administrative staff who attend the Hospital Advisory Council meetings.

\section{Social Services}

Most White Shield applicants are referred through the State of Oregon Children's Services Division; however, some referrals are received from private agencies or individuals. The admission process requires that each applicant be reviewed at an admissions meeting to be sure that white Shield is the appropriate placement for her.

The White Shield Social Service Department provides a variety of services to each resident on an individual need basis. One-to-one counseling includes assisting residents to make a decision in regard to keeping or releasing her infant, adoption planning, arranging for an outside living situation, and coordinating follow-up services. This department also provides group counseling geared toward coping with group living and interaction, and dealing with common issues that accompany teenage pregnancy, single parenthood, and motherhood in general.

The Social Service Department puts an emphasis on coordination of services and communication among the various departments at White Shield for the purpose of providing 
consistent care to all residents. A meeting with a representative from each department is held weekly and titled the Individual Planning Meeting. The purpose of this meeting is to discuss issues relevant to each individual client, to plan the services which can be most useful for each client, and to see that each department is aware of the needed services in order to provide them. Each girl is presented at the Individual Planning Meeting soon after admission and reviewed thereafter on a regular basis.

The staff of the Social Services Department consists of a full time Director, a full time intake worker, one full time social worker, two part time social workers, a consulting psychologist, and students from various counseling and social work programs in the Portland area.

\section{Food Services}

The dining room and kitchen are located in the administration bailding next to the hospital entrance. All meals are prepared by a food service staff. The staff includes one full time cook, one full time cook and kitchen helper, one full time kitchen helper, one part time cook and a part time kitchen helper. The. White Shield Home Administrator prepares the menu and orders the food.

\section{Chapel and Religioùs Services}

A chapel is located in the same building as the classrooms. Every Sunday a non-denominational şervice is 
broadcast, over the intercom system into the residence and girls are invited to come to the chapel at that time. There is a Bible study every Monday evening which girls are also invited to attend. Attendance for chapel is not mandatory. A staff chapel is held on Wednesday mornings and all staff are invited to attend that service.

\section{Recreational. Services}

White Shield Home employs one part time Arts, Crafts and Leisure Time Director in charge of recreation. This employee providès various arts and crafts classes and arranges outings:for residents which may include shopping, a circus, movies, concerts, swimming, or picnics.

\section{Girls' Council}

The Girls' Council is made up of six residents who volunteer to participate. There are three officers: President, Vice-President and Secretary, who are elected for four-month terms by the members of the Council. A Residential Child Care Worker is advisor for the Council. Girls' Council operates in a democratic manner and works toward the goal of representing all reșidents in presenting needs and wishes to White Shield Home decision-makers. A major function of Girls' Council is to plan and help carry out desired recreational activities. Gịrls Council also serves as a welcoming committee for incoming, residents. 
EARLY HISTORY AND BEGINNING OF THE PORTLAND WHITE SHIELD HOME

The Salvation Army opened a home for unmarried mothers in Portland in 1899. At that time, the home was a fourteen room frame building, formerly a private residence. In 1920, this home was purchased from the E. Henry Wemme Endowment Fund. In order to understand this interesting but complicated transition, it is necessary to present some of the history of E. Henry Wemme.

E. Henry Wemme was born in Crostau, Germany, and, in 1879, at age eighteen, received a passport to come to the United states to find employment. Wemme was crippled by a fall from a pole while doing electrical work in Chicago in 1880. A family named Reardon took Wemme in for about ten weeks. Wemme saw Mrs. Ann Reardon perform many "acts of kindness for destitute people."1

Ann Reardon made a deep impression upon Wemme, who then and there formed a decision that if he ever acquired anything worthwhile, he would make provisions for the poor and particularly for wayward, unmarried girls.2

In 1881, Wemme decided to make Portland, Oregon his home. At this time Wemme was in a partnership known as "Hendrickson and Wemme", which involved the manufacturing 
of tents, awnings, sails, horsewagon waterproof covers, flags and dealings in oil clothing.

In 1889 , the telephone directory listed Henry and his brother, August, as operating the Willamette Tent and Awning Company, but August did not continue to work for his brother long.

In the 1890's, during the Alaskan gold rush, E. Henry Wemme did a highly profitable business selling tents.

In 1889 , Wemme bought the first automobile to make its appearance in Portland, and later bought the first airplane that came to Portland. In 1912, Wemme bought the Old Barlow Toll Road which was the first road to cross the Cascade Mountains.

As for his personality, Wemme usually dressed like a poverty stricken laborer. He seldom wore pressed clothes or had his shoes shined and he was generally unshaven. He was always mouthing an unlighted cigar, the liquid qualities of which ran down both sides of his mouth and chin. He worked like a horse and lived like a hermit. ${ }^{3}$

On December 27, 1913, Wemme executed his own will which contained the trust that created the E. Henry Wemme Endowment Fund. The purpose of the trust was to build, equip, and operate a maternity home for unfortunate and wayward girls to be known as the White Shield of Portland, Oregon. "The maternity home was to be operated as a lying-in hospital."4 The language verbatim of the portion of E. Henry Wemme's will pertaining to the creation of the Endowment Fund is included 
in Appendix A. E. Henry Wemme died on December 17, 1914, at the age of fifty-three.

There is nothing to indicate that Wemme sought to imitate C.N. Crittenton, who was the founder of an international string of Florence Crittenton Missions for unmarried mothers. 6

Upon execution of Wemme's will, the women of the board of the Portland Florence Crittenton Mission Home donated their home to the E. Henry Wemme Endowment Fund.

Three years after Wemme's death this home was given to the Church of Christ Science, as had been designated in Wemme's will. After a few months of operation, the Church closed the home and refused admittance to any of the persons stipulated in the will. At this time, the Church sold the home to the Salvation Army which began to operate it.

August Wemme, Henry's brother, and others brought a lawsuit against the Church of Christ Science in 1923, alleging that the wishes of E. Henry Wemme were not being carried out as designated in his will. The court's decision can be summarized as follows:

1) The court held that Wemme's trust was not void for uncertainty.

2) The court held that while the Christian Science churches had violated the terms of the trust, yet this being a public charity, it would not be allowed to fail.

3) The court denied all relief to August Wemme and the other foreign heirs. 
4) The court required the Christian Science churches to account to the five court-appointed trustees for every dollar which they had received from the trust in any manner whatsoever.

5) The court allowed the conveyance of the White Shield Home to the Salvation Army to stand, but required the Christian Science churches to account to its court-appointed trustees for the proceeds received by the churches. 6

Other cases followed this principal case of August Wemme, et al. versus First Church of Christ, Scientist, et al. All these cases were in one way or another related to the Wemme Endowment Fund. Some had to do with court allowances for attorney fees and others had to do with different phases of the trust, but relief was denied on the grounds that the first case settled all questions.

As a result of these cases, the court-appointed trustees did not have enough money left to build and efficiently operate a maternity home. About 1931, the board of the Florence Crittenton Refuge Home came through with a proposal. The board realized the need of the Wemme trustees for a maternity home so they offered to donate the land and buildings located at the corner of East 31st and Glisan streets to the Wemme Endowment Fund. The name of the new operation was the "E. Henry Wemme White Shield of Portland, Oregon", differentiating it from the White Shield Home owned and operated by the Salvation Army. On August 6, 1942, an arrangement was made whereby the operation of the E. Henry Wemme White Shield of Portland, Oregon was delegated to the 
Salvation Army which could operate the home more economically and efficiently than if operated by the trust.

Accordingly an order was taken by the Circuit Court dated August 6, 1942, confirming an arrangement between the E. Henry Wemme Endowment Fund and the Salvation Army whereby the Wemme trustees still retained visitorial power and control over the E. Henry Wemme White Shield but left the details to the Salvation Army. 7

In 1950, the City of Portland fire marshal concluded that the premises of the E. Henry Wemme White Shield of Portland were unsafe. Finally the use of the home was discontinued and the work of the Wemme Endowment Fund was continued by the Salvation Army at its White Shield Home. Various contractual agreements were made until a workable arrangement resulted. The arrangement went as follows:

1) The Salvation Army deeded to the E. Henry Wemme Endowment Fund approximately one acre of land in Portland, Oregon, immediately adjoining the White Shield Home owned by the Salvation Army .

2) Upon this acre of land the E. Henry Wemme Endowment Fund constructed a modern maternity or lying-in hospital with fourteen beds for patients plus two beds for delivery purposes, costing approximately $\$ 125,000$. Everything in connection with this new hospital was to be and is of the best quality and design.

This hospital was dedicated as the E. Henry Wemme Memorial Hospital by appropriate ceremonies held on Sunday, June 24, 1951.

3) The E. Henry Wemme Endowment Fund entered into a contract with the Salvation Army for operating this maternity home or lying-in hospital in conjunction with the White Shield adjoining; thus the maternity home or lyingin hospital can be used to accommodate 
unmarried mothers, whereas rehabilitation and such other work as is needed for the care and training of such mothers can be performed at the White Shield Home.

4) The E. Henry Wemme Endowment Fund pays to the Salvation Army a monthly sum for such operation. The order for the acceptance of the deed from the Salvation Army covering the land above referred to and the contract and other arrangements, including operation by the Salvation Army, was entered on June 28, 1950.8

"Thus the dream of the donor and of all who have helped to carry out this trust has come true."9 
CHAPTER IV

THE CHANGING INSTITUTION

The 1940's

In 1942, the Salvation Army began operating the E. Henry Wemme White Shield of Portland, Oregon, in conjunction with the Salvation Army White Shield Home. At this time the two homes were located in different parts of the city. The E. Henry Wemme White Shield Home was located at 3115 N.W. Glisan and the Salvation Army White Shield Home was located at 2640 N.W. Mayfair. Since that time, the Salvation Army White Shield Home address changed only as a result of a change in street names, not as a result of relocation. The address now is $2640 \mathrm{~N} . \mathrm{W}$. Alexandra.

In a report from the Council on Social Agencies dated June 8,1945 , the purpose and scope of the two homes was described in the following manner.

(The agencies) care for unmarried mothers or deserted mothers and their babies born during residence in an institution. Admission through court committment (sic) or personal application. No limitation as to race or creed. Non-venereal cases. State-wide.

White Shield--younger girls, with capacity of 35 girls.

Wemme--older girls, with capacity of 33 girls. 
Both buildings have dormitories and some private rooms for the girls. Medical care is provided by a corps of doctors, each assigned for part-time duty during one month of the year. Cases coming to the home in emergency are sent to the County Hospital. Admission is handled by the superintendent and caseworker. Home is directly responsible to regional office in San Francisco. Local Salvation Army receives funds for support and distributes to Home. 10

The same report described the personnel. The staff at. White Shield Home included a superintendant, a caseworker, a cook, a bookkeeper, a hospital assistant, house officers (all members of the Salvation Army), two trained nurses, and three attendants. The superintendant and the caseworker served both institutions. The staff at Wemme included an assistant superintendant, two Salvation Army officers, and a nurse. In 1944, an increase of 54 girls were cared for over the 1943 census. This was due to the use of Wemme Home and the additional equipment. The report listed some proposed changes.

1) All girls will be admitted at Wemme and will remain there until a few weeks before delivery. They will then be transferred to the White Shield Home, remaining there until discharge.

2) Girls will remain under care for shorter periods than before, possibly six weeks to two months before delivery.

3) Discontinuance of deliveries at Wemme and reorganization including repairs to delivery facilities at White Shield. The agency has a request for $\$ 4,375$ for repairs pending in the Chest Budget Committee.

4) Plans for girls and babies are to start at time of admission. 
5) School will be transferred to Wemme Home if space is available.11

Recommendations in this report included:

1) That the agency should be commended for the attitude of its new superintendent in tackling some of the organizational problems within the institution, and for her interest in using the services of other agencies in planning with the girls.

2) That the Salvation Army Board become familiar with the policies and activities of the two homes and take an active part in decisions made on changes. The executive of Salvation Army submitted the board list with a comment that 'this board is advisory only and has no legal status.' The Council questions funds from private or public agencies allocated to an agency with the executive empowered to make all decisions or distribute funds to an agency over which they have no control.

3) That the terms of the agreement of 1941 accepted by Salvation Army and Oregon Protective Society be followed. Salvation Army agreed to care for non-infected unmarried mothers, Oregon Protective only venereally infected unmarried mothers. The Council reports Salvation Army is referring to Louise Home non-infected girls who do not conform to the rules and regulations of the homes, which is in violation of the agreement as well as the license. This should be discontinued or discussed with the Council of Social Agencies and the State Public Welfare Commission. (Later: This has been discussed with White Shield and the State Public Welfare Commission and only a few cases are transferred. These come from out counties when the major problem is delinquency and not yet maternity. When girl is four months pregnant, cases are transferred to White Shield Home.)

4) The Council questions the need for a hospital delivery service at the home, especially now since complete renevations (sic) for the hospital department at White Shield appear necessary and the hospital department at Wemme is about to be discontinued. If arrangements can be made at Multnomah County Hospital for resident cases and at private hospitals on a fee basis for resident and non-resident cases, 
the Council believes the agency should discontinue delivery at the home. This would allow. available space to be used for additional cases on the waiting list and the staff time to be used in helping girls in their adjustment to community life. This matter should be considered before the agency receives funds for remodeling hospital rooms. (Later: Public Welfare Commission with Major Flack who opposed such a plan.)

5) That casework services be strengthened. A full time qualified caseworker should be employed. There is a caseload of 55 girls in the homes (April 30, 1945) plus the follow-up with girls who have been discharged from the homes. The 1931 survey includes this recommendation.

6) That a small council committee of agencies concerned with services to unmarried mothers be appointed to plan jointly for the total community services to this group. They should formulate procedures of intake and referral of the girls and their babies to agencies for other needed services, including adoption, etc.

7) That the use of all community resources to meet the individual needs of the girls be kept in mind at admission.

If recommendations 4,5 and 6 were followed, more girls could be cared for in the homes within a year, and it is even possible that Wemme Home eventually might be closed. The Committee deplores the use of the unattractive, barn-like and unadaptable building for this type of care.

8) Plans for changes as outlined by Major Flack which call for a reorganized program should be submitted in writing to the Council and be considered in light of other community services by the Council, Chest and State Public Welfare Commission before action is taken. 12

Another study of various community agencies was completed in the forties (specific date not available). This study was undertaken to study present agency function with present available staff, funds and facilities. The agencies 
that participated in the study include the Red Cross, Boys and Girls Aid, Salvation Army White Shield Home, Volunteers of America, Multnomah County Public Welfare, Jewish Shelter Home, Catholic Charities, Incorporated, and Oregon Protective. The questionnaire used for this study is provided in Appendix B. No further information about the study or who made it accompanied the print-out. However, the results are valuable in that they are supportive of the services provided by White Shield Home.

A summary of the results states that unmet needs are reported to exist in all areas (services in their own home, services in foster homes, and services in institutions for unmarried mothers) but there seems to be a general agreement to the effect that there is greater unmet need in relation to the care of unmarried mothers and their children in their own homes or in foster homes before "confinement", than in the service that is provided to them in maternity homes and the help that is available in establishing themselves in a home or in getting a job after "confinement". 13

The Child Welfare Review Committee made some tentative recommendations which were printed on May 14, 1946. Prior to their recommendations, the Committee commended the Salvation Army White Shield and Wemme Homes on: "1) the better physical and medical care that the girls receive; 2) the increase in the number of cases cleared with the Social Service Exchange; 3 ) and the increased activity of the. 
Guild."14 The recommendations by this Committee report were listed:as: follows:

1) That the Salvation Army White Shield and Wemme Homes cooperate more closely with the Council on Social Agencies particularly in giving information in regard to present program and plans for expansion.

2 ) That these Homes offer the girls a constructive recreational and educational program including activities which may be vocationally helpful later, and which also may help the girls to be better housewives and mothers.

Baby care and activities which offer them both physical and mental outlets, such as trips, hobbies, movies and games were suggested as consistent with the national policy.

3) Also in the light of the national intake policy, it was suggested that the shortness of the period of care be re-examined in the light of the girls' needs for good pre-natal care and rehabilitation.

It was felt the major services of the Homes should be in this area and it should not be considered purely a hospital.

The physical, mental, and moral dangers to mothers in waiting until six weeks before birth and to both child and mother in too early release from the Home should be seriously considered.

4) That the question of the need for expansion be further studied in the light of the agency's drive at present to publicize the service, and the question of whether a larger number of applications are received.

The reduction in number of applications and admissions in 1945 and the increase in illegitimate births was noted.

5) That the hospital facilities be improved including sound-proofing according to the standards of the best maternity hospitals.

6) The need has been strongly indicated for institutional care for special cases such as delinquents, feeble-minded, and training school girls. 
The Committee recommended that the creation of a special small facility for this group be discussed, including the effect of the Hillcrest girls now admitted to the White Shield Home.

7) That the Advisory Board be given as intimate a knowledge of the Homes and as much authority as possible, and that this Board be rotated.15

By reviewing the sample of case record material of the 1940's, the median age was found to be eighteen. The oldest resident of the sample was thirty-five, the youngest fifteen. In regard to race, all members of the sample were Caucasian except for one, who was Indian. About 58 percent of the sample came from single-parent homes in 1940. This is not just to say that the parents were divorced, but that possibly a death occurred as a result of accident or illness. It must be recognized that these results cannot necessarily be considered representative of the whole White shield population as the sample was to small.

In a report completed by the Portland Council of Social agencies on May 31, 1946, statistical data were revealed. (See Table I.) 16

\section{TABLE I}

COMPARATIVE DATA, 1944-1945

Total mothers under care: Wemme White Shield

Total mothers in both Homes Dec. 31 Days Care in both Homes

Total babies under care: Wemme

White Shield

Total babies in both Homes Dec. 31 Days Care in both Homes (babies) $\frac{1944}{120}$

111

60

17,325

103

76

28

11,756

$\frac{1945}{87}$

150

37

16,163

61

103

7

7,210 


\section{The 1950 's}

In a pamphlet put out by the Salvation Army Women's Social Service Department on January 5, 1956, titled "Ten Year Report of Services for Calendar Years 1945 thru 1954" a page was devoted to describing the patient served. The words chosen and the manner in which this description is written is self-revealing: 17

In ten years we have seen her by the thousand.

We offer her more than shelter and food. She does not stay with us so long anymore.

More frequently she releases her baby for adoption than she used to.

She is younger today as our increased school program will attest.

She does not feel the need for anonymity that she did ten years ago.

She is frequently pretty disturbed emotionally.

She is 12 or 40 . She is sophisticated, naive, school girl, teacher, any race, any creed, any age.

She is going to have a baby.

\section{For Her:}

Our home is a haven

Our staff--her family

Our care--her courage

Our chapel--her sanctuary

Our faith in her--her greatest strength

Our God--the answer to her need.

She comes to us of her own accord. She leaves us with Our Blessing.

For God Himself enlarges the boundaries of our heart to care for them all.

SO LOVE AND SKILL WORK TOGETHER AND WE HAVE THE MIRACLE. 
In this same report, an age breakdown is given over the ten year period, 1945-1954. (See Table II.) 18

\section{TABLE II}

AGE DISTRIBUTION, 1945-1954

Portland Wemme

Portland White Shield

Year Under 16 17-20 Over 21 Under 16 17-20 Over 21

1945

2

51

55

1946

1947

1948

1949

1950

1951

1952

1953

5

36

13

31

69

16

20

17

100

41

17

101

55

23

100

37

25

103

58

22

140

63

130

56

28

112

52

22

110

32

1954

25 35

TOTAL

1,718

The report also lists the current staff of the home in 1945 and $1954: 19$

$$
\begin{aligned}
1945 \text { - } & \text { Major Mildred Platt, Supt. } \\
& \text { Major Magna Sorenson } \\
& \text { Adj. Laura Wedlund } \\
& 1 \text { - R.N. } \\
& 1 \text { - Caseworker (part-time) } \\
& 7 \text { - employees }
\end{aligned}
$$

Wemme Annex:

Major Ethel Hunter

Capt. Charlotte Leonard

Major Minnie Reeves

1 - R.N.

1 - employee

1954 - S/Captain Ellen Barton

Major Isabella Dye

1/Lt. Phyllis Griffin

$2 /$ Lt. Nona Pryts

$2 /$ Lt. Viola Holm

Pr. Lt. Sylvia Mitchell, R.N. 


$$
\begin{aligned}
& 3 \text { - R.N.'s } \\
& 2 \text { - Caseworkers } \\
& 9 \text { - employees }
\end{aligned}
$$

At the Hospital Advisory Council Meeting on January 23, 1958, a discussion centered around an open house to be held on January 31 , 1958, for the new school.

At another Hospital Advisory Council Meeting held on December 16, 1959, four committees of the board were established for improved organization of the board. The committees include the following: the Executive Committee, the Finance Committee, the Medico-Administrative Committee, and the Nominating Committee. 20

The sample of case records for the 1950's shows a median age of eighteen as in the forties, with the youngest of the sample being fourteen, the oldest twenty-three. There is also little change in regard to race according to this particular sample. All members were Caucasian except for one who was Black. About 42 percent of the sample of the 1940's came from single-parent homes. The sample shows an increase in mothers who decide to keep their children in the fifties, from 16.6 percent in the forties to 58.3 percent in the fifties. The statistics show a greater number of girls receiving state aid than in the forties, from 25 percent in the forties to 91.7 percent in the fifties. About 33 percent of the alleged fathers from the sample of the fifties acknowledged paternity as did 33.3 percent in the forties. 


\section{The: $1960^{\prime} \mathrm{s}$}

More information was available for this study from the $1960^{\prime} \mathrm{s}$ and the $1970^{\prime} \mathrm{s}$, than there was from the 1940's and 1950's, consequently more material will be presented for these years. However, this is not necessarily to say that there was an increase in activity for the sixties and seventies, but just that the material available was more extensive.

During the 1960's there was a great deal of discussion surrounding the physical setting at White Shield. The early sixties brought discussion for renovation of business offices and interviewing rooms, discussion on the possibility of enlarging the home by a new addition and other remodeling proposals. On April 2, 1964, a discussion at a Hospital Advisory Council Meeting centered around the possibility of constructing an entire new building followed by a replacement of the old building. On November 18, 1965, some preliminary drawings of proposed expanded facility and remodeling plans were presented to the Board, and the next month submitted to territorial headquarters of the Salvation Army in San Francisco. Möre discussion regarding the building plans occurred at several Hospital Advisory Council Meetings until revised plans went to territorial headquarters on September 14, 1966, to await approval. Excavating and building began in June of 1967, but in October of 1967, the construction was halted due 
to lack of funds. Once again, major alterations were made on the plans. The altered plans requested that the new building house sixty girls rather than the original seventy to seventy-six girls, and that the present building be converted to dining facilities, school rooms, and administrative offices. A final decision on the building plan was presented on January 4, 1968, and stated:

We will have a $147^{\prime} \times 45^{\prime}$ wooden building with concrete footing and brick facing. This building will be a residence for 72 girls and 4 staff members. An architect is working on the plans. This is phase \#1. Phase \#2 will be a new kitchen and dining area. If this is not feasible, the alternate is a new chapel and school rooms. Phase \#3 is a new administration and school facility. 21

The building plans were approved; a bid was accepted and the construction began. On April 3, 1969, the new residence building was completed and occupied. The second floor of the old building was still being used for overflow, but there was no longer a waiting list. Another building comprised of school rooms and the chapel was also completed at this time.

A major issue in the sixties was public relations. There was much discussion on methods for improving the home's public relations. Some suggestions included organizing a speaking group, involving women's clubs, the use of radio, television, the Oregonian, and the Reporter.

The school program was a major issue in the sixties also. On January 5, 1961, a report was given at the Hospital 
Advisory Council Meeting on the school program at White Shield Home. It stated that the school program was established in 1951, was state supported, affiliated with a local high school, and that more than 500 girls had attended this school since the program began.22 A problem came up in regard to the school program in late 1962. A need for an elementary grade level had arisen. Only a few girls of this age resided at White Shield Home, but a great necessity was felt to provide school for them. It was found that the Oregon law provided for the establishment of elementary education facilities at the home, but many problems remained to be solved. In February of 1963 , it was reported that a full time teacher could be hired to teach elementary school for the following Fall if the state budget would permit it. In 1965, a panel discussion was held at a Hospital Advisory Council Meeting for the purpose of presenting White Shield Home's "unique school program". The panel described how the school was started and how it had grown. Since 1951, the school had allowed 753 girls to continue their education without interruption.

Another issue regarding education came up in 1969, because of controversy in regard to sex education. A retired army nurse, Mrs. George Carey, attended a Hospital Advisory Council Meeting to speak on sex education in schools. Several members of the board were appointed to go over material submitted by Mrs. Carey. Their purpose was stated as follows: 
It was hoped we might assist with a program that could offset some of the information which Mrs. Carey says is now available to our young people in schools and which she feels is not a practical or realistic approach to it. 23

The Report continued:

After considerable discussion, it was the conclusion (in which Major Snider concurred) that the Salvation Army or White Shield Home should not get involved in trying to tell the schools what kind of sex material to use or how to teach it. This is a hotly debated topic in American Elementary Education. Young people hear about sex at home, in the classroom, books, T.V., as well as through many other avenues. Certainly most of today's parents are not capable of presenting it to their children. All young people have a right to have sex explained and to have their questions answered intelligently. After all, the sex issue is as old as the fig leaf, but there is no question but what better teaching methods are needed in our sex saturated society. The present revolution by angry and hysterical parents, as well as the public generally indicates it. 24

The Committee determined the manner in which White

Shield could assist in sex education:

Our committee thinks White Shield Home can assist in the dissemination of proper sex education by expanding the type of program it has been presenting for years on a small scale, namely to have qualified speakers, with factual material, appear before groups, schools and organizations, telling them:

1. What girls experience after they become pregnant and after they enter the White Shield Home.

2. What this mis-used sex experience does to girls in the way of trauma, the heartbreak of keeping or giving up their child, the high possibility of venereal disease, and when they become engaged to be married whether or not they should tell.

3 . How the involved boys feel and their attitude today as compared with several years ago.

4. Use case examples. These make indelible impressions on those who hear them. 
In early 1962, some problems arose regarding adoption. Adoption agencies were having difficulty finding adoptive homes. This was again an issue under consideration in October of 1966. At a Hospital Advisory Council Meeting on September 24, 1968, adoption was a major topic of discussion. It was noted that there is a limited capacity of adoption agencies for receiving babies in the Portland area due to the following reasons as listed in the Board Meeting Minutes.

1) Closing out of Albertina Kerr as a baby home.

2) Waverly's changes in program to become a Children's Home.

3) Curtailed budgets of State Welfare and their vacillation between currently popular psychological theories.

4) Shortage of foster homes. 26

It was suggested that there was a need for better communication and better understanding of working procedures between White Shield, the above-mentioned agencies, Boys and Girls Aid Society, Jewish Welfare, and Catholic Charities. ${ }^{27}$

Also in the early 1960 's, White Shield Home was appealing for more personnel to include an additional caseworker and an additional secretary. In 1964, a new staff physician for the Home was introduced and in 1965, a new bookkeeper joined the staff, replacing the previous bookkeeper.

A group of community residents formed a White Shield Women's Auxiliary. Money was obtained through dues paid by 
the members and fund raising projects which they held. These funds were used to purchase various furnishings, equipment, and gifts for White Shield Home and its residents. The Women's Auxiliary was active for White Shield in the 1960 's. In 1964, the Women's Auxiliary voted to purchase a ceramic kiln for the girls as a Christmas gift. They also purchased four new sets of box springs and mattresses and paid for repairs on the venetian blinds. In 1966, the Women's Auxiliary bought table linen and dishes for the girls dining room, and in January of 1967, purchased a mimeograph machine and twelve rugs. In 1969, the Auxiliary purchased draperies for the staff dining room.

By 1962 , a beauty shop had been completed for the girls use. Money from the E. Henry Wemme Endowment Fund was used for this project. In 1963, it was reported that the shampoo room was in constant operation; 624 hairdos were given, and also considerable instruction on beauty care. 28

By 1963, dental facilities had been installed at white Shield. One complete unit had been donated by the Shrine Hospital in 1962. Girls were able to receive dental care conveniently at the Home.

In 1964, research on heart murmurs was being carried out at White Shield Home. The purpose was to determine frequency and development of heart murmurs during pregnancy.

On March 3, 1965, the Salvation Army released an official Policy Statement on Non-discrimination in regard to 
race, creed, or national origin. A copy of this policy is included in Appendix $C$ of this paper. Prior to this time White Shield had no official policy on non-discrimination. The fact that it was an issue in the mid-sixties reflects a common concern about discrimination occurring in the nation at large.

A guest at the Hospital Advisory Council Meeting of March 3, 1965, Portland City Commissioner Glen Ryan reviewed the history of the work done by the Salvation Army when they first extended help to the prostitute on the street.

He emphasized that the whole purpose is to try to change the girl, and after all the care and counseling, it is hoped that the girls will see the Love of God. This is what we want to do, help people find Jesus. 29

Included with the Board Meeting Minutes of the sixties, was a print-out titled "Notes on Salvation Army facilities tour with Captain Jack Grable, February 16, 1966: White Shield Home and Wemme Memorial Hospital for Unwed Mothers." These "notes" are descriptive of the Home, staff, and residents, before the new residence was built. A copy of this report is included in Appendix $D$.

Some comparative statistics for the ten year period, 1954 through 1963 are also provided in Appendix E. Some observations drawn from the statistics and which were attached read as follows:

From 1959 through 1963, The Salvation Army White Shield Home and E. Henry Wemme Memorial Hospital cared for 280 more in-resident unmarried mothers than were served from 1954 through 1958. This increased use of the facility can be accounted for 
by the increased education of the public through many channels, i.e.., T.V..; radio; newspapers; magazines; tour groups; speaking appointments. Many more professional people--doctors, attorneys, teachers, ministers, public health nurses, are recognizing the value of services offered and we, ourselves, are constantly evaluating, improving and up-grading the program.

In addition to these factors, bed space for 9 additional residents was created by utilizing every possible available space. There is now no other bed space available and the dining room, school room, chapel and other congregate rooms are totally inadequate to give the best possible care to those awaiting to be confined to our hospital.

It is our guess that there will be little or no increase in number of unmarried mothers cared for in residence during a given year and little changes in days care until present facilities are expanded to meet some of the pressure need. For almost four years, we have operated at capacity with a waiting list. 30

These statistics and observations helped stimulate the construction of a new residence.

Early in the sixties, it was apparent that the home was becoming very crowded and that the services provided were very much in demand. Already White Shield Home was asking for increased support from United Good Neighbors. In the summer of 1963, the Home was filled to capacity, the waiting list reached a high of forty-two persons, and there were the highest number of deliveries in September of 1963 in the history of White Shield Home. In 1964, the waiting list reached another high of sixty. In 1966, it was determined that a girl could not be brought into residence early in her pregnancy as there just was not enough space. Around 
this time, an outpatient plan came into existence whereby a girl could receive her medical care, counseling, and schooling at White Shield while living out of residence; then approximately two weeks before her expected due date she would move on campus to prepare for delivery.

In 1965,700 girls received direct services but did not enter the Home. (See Table III.) ${ }^{31}$

\section{TABLE III}

CIRCUMSTANCES FOR NON-ADMITTANCE, 1965

$\begin{aligned} 310 & \text { made contact and then dropped out } \\ 131 & \text { chose to work with another agency } \\ 100 & \text { could not be served because of no vacancy } \\ 46 & \text { inquiries too close to due date } \\ 11 & \text { terminated in marriage } \\ 7 & \text { notifications of miscarriages } \\ 39 & \text { terminated for miscellaneous reasons }\end{aligned}$

Due to expanded facility in 1969, White Shield was able to give increased services to unwed mothers. As described in the Hospital Advisory Council Meeting Minutes, these included:

1) Temporary housing while girl makes a decision as to what she is going to do.

2) Encourage girl to come into residence earlier in her pregnancy and continue to work at her place of employment.

3) Extended care following delivery enabling the girl to work out a better living arrangement and not go back into the environment from which she came.

4) Offer abortion counseling.

5) Mother and child accommodations while the unwed mother is awaiting the birth of another child.

6) Day care for a child whose unwed mother is at work. The mother could live in residence or elsewhere. 
7) Set up a pregnancy diagnostic center.

8) Counseling service to be established for those who are involved in and related to the unwed parent situation--ministers, teachers, etc.

9) Preventive counseling. 32

The sample taken for this study shows the median age of White Shield Home residents for the sixties as eighteen, with the youngest fifteen, the oldest twenty-four. All members of the sample for the sixties are Caucasian. About 33 percent of the residents are from single-parent homes according to the sample. About 58 percent of the girls released their children for adoption. The same percentage, 91.7 percent, obtained state aid in the sixties as did in the fifties. About 42 percent of alleged fathers acknowledged paternity in contrast to 33.3 percent in the forties and fifties.

\section{The $1970^{\prime} \mathrm{s}$}

The leading issue for the early 1970's for White Shield was their rapid decline in occupancy. The occupancy rates for September 1969 through March 1970 are shown in Table IV. 33 The probable reasons for this rapid decline were partially the liberalized abortion law in Oregon in August of 1969, and partially the changing values of society regarding illegitimate children. It became more acceptable to have a child out of wedlock and to raise it. This presented a serious problem for White Shield as the agency could not afford such a drop in clientele. The question 
TABLE IV

OCCUPANCY RATES

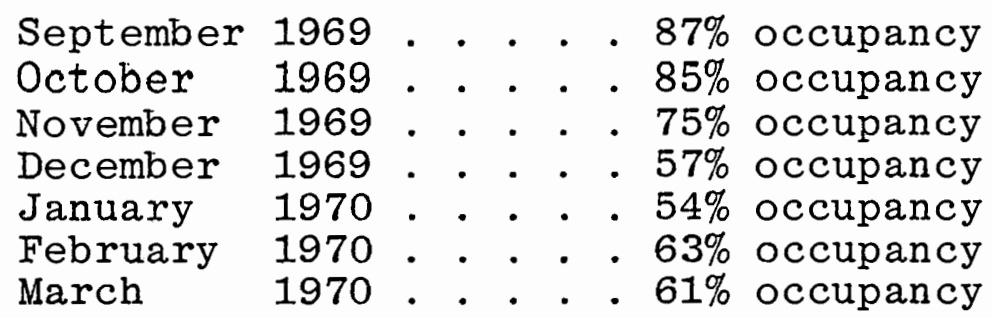

at this point was, "Where do we go from here?" A Report

of Current Service came out in November of 1970, written

by the Director of the White Shield Social Services Department which described the situation in this manner.

We must be prepared not only to be flexible ourselves, but also to accept some of the unusual situations that are going to arise. A lot of our Homes and similar facilities have expanded into the area of crises centers and drug control. We think maybe here at White Shield, because we have been the only resource of our kind in the state, we are really dedicated to the service of the unwed parents. We wonder if we can't maintain that image. ${ }^{3}$

In regard to abortions, the report states:

We are not doing abortions here, of course, but if a girl comes to us wanting an abortion, we will direct her to a reputable place. I feel this rush for abortions is a fad and 'will die down and take it's proper place'. 35

The Hospital Advisory Council Minutes of April 8, 1971, reflect concern over the decline in occupancy:

There are large groups of women having babies and they are not married, some continue to live together as couples, they are breaking down the stigma of unwed pregnancy so that the need for this as that type of institution is not needed. Capt. Maynard said that this is the kind of statement that she has heard since she has been 
here and this is what indicates the insecurity of the services at White Shield as they are currently. However, forty-two girls or young women a day were cared for within the residence in 1970. Twelve to thirteen per day were cared for out-of-residence. That represents a lot of service and a lot of care. ${ }^{36}$

The Minutes continue:

Captain Maynard stated that she is 'not sure what need is forthcoming, but surely it is not the answer to say to young women here is a contraceptive or, here we are providing an abortion. It doesn't seem this is going to solve the problem for pregnancy out-of-wedlock. And it does seem that the great basis for conclusion that there will be no need for this kind of service is the thinking that with the availability of the contraceptives and the liberalized abortion law

'Why would anyone need White Shield?' It might be after the pill and a couple of abortions, but we still seem to have to find a different answer to cope with the problem of pregnancy outof-wedlock.'

The chairman of the Council set up a committee at this meeting to learn facts, state the problems, and all of the possible solutions, so that in May some decisions could be made in this regard.

On August 12, 1971, the discussion at the Hospital Advisory Council Meeting centered around potential linkage with another agency, possibly Residential Manpower or Vocational Village. Residential Manpower was an educational and job training program. It was felt that if a financial arrangement could be secured, White shield residents could receive education or training at Residential Manpower and persons in the Manpower program could receive job training at White Shield. 
Vocational Village was a center that provided various programs in vocational training. A linkage with Vocational Village was considered in which white Shield residents would be provided with a resource from which to obtain vocational training.

Two other proposals were also discussed:

1) that the Salvation Army establish, own and operate a Day and Night Young Child Care Center with funding through 4-C. The Child Care Coordinating Council, 4-C, is administered through the State with Federal and State funding.

2) that the Salvation Army White Shield Home and Portland Public School District expand services. 38

The committee elected to investigate and recommend additional services for the White Shield Home and Hospital came up with these results on September 9, 1971:

Criteria for the additional services:

1) Existing need in the community we serve

2) Fits the Salvation Army concepts of service to those needing it.

3) Compatible with existing services to pregnant unwed mothers.

4) Generally uses capabilities of present staff and facility.

5) Financially acceptable.

Additional services to be explored:

1) Psychiatric Day Treatment.

2) Senior Citizens Home.

3) Single girl--low cost housing.

4) Total service to pregnant unwed mothers.

5) Service to pre-delinquent girls.

6) Service to drug addicts.

7) Infant Day Care Center.

8) Abortion Service.

9) Federal Manpower Training Residential Service.

10) Mother/Child post-divorce care. 
Selection of best candidates--additional services:

1) Total service to unwed mothers.

2) Infant Day Care Center.

3) Federal Manpower Training Residential Service.39

Shortly after these discussions, and because a need was felt to keep the agency operating, White Shield developed a Mother-Child Program, now called the Infant-Maternal Program. In 1970, 37 percent of unwed mothers kept their children and in the first three months of 1971, 62 percent were keeping their children. It was felt that these mothers did not have appropriate accommodations or plans for raising their children. The Mother-Child Program was set up to offer services to these mothers for the purpose of providing counseling, temporary living accommodations, and parenting classes. The program began with only one mother and her child and continued in that manner for a couple of months. By December of 1971, the Mother-Child Program began to gain momentum. Other girls in the prenatal program began to apply for the Mother-Child Program after delivery of their child. It was soon determined that there was a need for a child care center for the mothers with infants residing at White Shield. This center could provide mothers in the Infant-Maternal Program with a day care where they could leave their children while they went to school or off campus to work. The day care could provide the infants with the physical care, emotional security, and stimulation necessary for healthy development while the mother was away. 
Application to license the Child Care Center began in December of 1971.

Demands for White Shield services became heavy and challenging at this time. White shield requested an emergency grant from United Good Neighbors to maintain itself while developing further programs to keep the agency in operation .

In January of 1972 , the Child Care Center was licensed to serve a capacity of twenty children. At this time White Shield was also negotiating with the state to see if the State would buy services from the Infant-Maternal Program.

At the April 13th meeting of the Hospital Advisory Council, it was reported that the March occupancy rates showed a positive picture, that a relationship had been secured with Residential Manpower (which never materialized because of lack of funds), and that 4-C and Portland Community College were working closely with White Shield.

The Salvation Army requested a needs assessment study to be completed by the Tri-County Community Council covering the total services to unwed mothers in the Portland area. The purpose of the study was to determine what services at White Shield were valuable and what services could be added to better serve the community needs. A copy of the report from this study accompanies this paper in Appendix $F$. The findings strongly influenced changes necessary at white Shield in the early to mid-seventies. 
In a letter sent out to community agencies on August 7 , 1972, it was announced that services at White Shield had expanded to provide three programs:

1) Prenatal Program for Unwed Expectant Mothers represents 45 percent of the Home Care Service. It includes room and board, residential program, professional casework and group counseling, religious programs and counseling, medical care, educational and recreational programs. High school education is provided through affiliation with Portland Public School District \#1.

2 ) Post-Partum Continuing Program represents 5 percent of the Home Care Services. It is designed for the young mother who realizes a continued need for the supportive environment of White Shield following separation from her child. She receives help in working out and accomplishing specific goals for herself. It is a goal-oriented program and similar to halfway house care.

3) Mother-Child Program represents 50 percent of the Home Care Services. This program is designed to give 24-hour care to the single, dependent mother with her child. In 1969, only 22 percent of the mothers kept their babies. In 1971, more than 60 percent kept their infants. This new service offers comprehensive, tangible help to both mother and child. It includes instruction in mothering, housekeeping, budgeting and other skills which will enable the mother to make a strong home for herself and her child. The mother sets goals for herself aimed toward adequacy and self-support as a head-of-the-household. Individual and group counselling (sic) is provided. Education, medical, religious and recreational programs are offered. The licensed Child Care Center is on the grounds. 40

A copy of this letter is included in Appendix $G$ of this paper. In 1973, there were five clearly defined programs at White Shield Home:

1) Prenatal Program (PNP)

2) Infant-Maternal Program (IMP) 
3) Wemme Maternity Hospital and Outpatient Clinic

4) Junior and Senior High School

5) Infant and Toddler Child Care Center

Another report on services at White Shield Home and Wemme Maternity Hospital written July 14, 1973, is located in Appendix $H$ of this paper as it is a descriptive summary of the programs at White Shield.

Related to the drastic drop in White Shield's occupancy in the early seventies, came an ever-increasing concern with public relations as in the sixties. In January of 1971, a new committee was set up within the Hospital Advisory Council to accommodate a recognized need for expanded public awareness. Mailing circulars around the state to make young people aware of White Shield's services was one method adopted. Publicizing White Shield was a continuous concern. In June of 1974 , the public relations committee invited officials from School Districts \#1, \#2, and \#3 to tour the White Shield School in an effort to promote White shield and the services provided there.

The Women's Auxiliary was again extremely active and helpful in the early seventies. In 1970, they painted the staff dining room, purchased draperies and a hot food table for the girls' dining room. The Women's Auxiliary was notably active in helping to prepare the residence for the MotherChild Program. In January of 1971, they had completed several projects: purchased linen and blankets for the residence, 
provided Christmas support ("money, time, talent, incidental packets"), and installed a hand railing on the outside stairway. In 1972 and 1973, the Women's Auxiliary funded the Beneficiary Training Program. This program "hired" and trained residents to do specific jobs around the agency, such as food services, day care help, telephone answering, etc. Also in 1972, Christmas gifts were bought for each girl by the Auxiliary. In 1975, the Women's Auxiliary. re-upholstered chairs and furnishings in the Infant-Maternal lounge, gave furnishings to the Child Care Center, donated serving bowls to the dining room, gave each girl a Christmas stocking with $\$ 2.00$ inside and each baby a stocking with $\$ 1.00$ inside, and purchased a stereo set for the recreation room.

Next to the low occupancy rates in the seventies, the second most critical issue faced by White Shield had to do with the contract between White Shield Hospital and Emanuel Hospital. In June of 1972 , a letter was received from Emanuel Hospital stating that the doctors would no longer be performing deliveries at White Shield Hospital effective July 15, 1972. White Shield pleaded for an extension until November 15, which was granted. White Shield staff and the Hospital Advisory Council members felt that the girls should continue to deliver their infants at White Shield instead of transporting them to Emanuel for two reasons: one being the financial aspects, and the other being the need for continuity 
of care to White Shield Hospital's patients. A discussion at the June Hospital Advisory Council Meeting centered around the options that the Salvation Army had, in terms of national policy:

1) Self-governing medical staff.

2) Affiliation with a teaching hospital.

3) Affiliation with the University School of medicine.

Another option discussed was to close the White Shield Hospital. 41

Due to the drop in occupancy rates and this medical crisis, one member of the board suggested that the board adopt the following motion: "The White Shield Advisory Council recommends phasing out the present White Shield Home/Wemme Hospital operations."42 The minutes of this October 19, 1972 , Hospital Advisory Council Meeting continued:

This action to be implemented only after a final presentation to our Funding Bodies and determining that there is not an acceptable financial answer. 43

The above resolution was re-affirmed six months later. In April of 1973, negotiations with Emanuel Hospital were still in the process. In september of 1973, most babies were being delivered at Emanuel Hospital, but some emergency deliveries were still being done at White Shield Hospital. In January of 1974, White Shield attempted to utilize an ambulance service for transporting residents to Emanuel for delivery, but the question still existed: "Was it feasible to continue operating White Shield Hospital?" In September of 1974, the issue was still a priority for White Shield. Some members of 
the council were recommending closure of the hospital, others were requesting affiliation with University Hospital North. Options were being researched once again by the Medical Advisory Hospital Committee. They met with representatives from Emanuel Hospital, University Medical School, and Good Samaritan Hospital regarding possible affiliation. A question came up in regard to treating other patients in the hospital besides unwed mothers, and it was recognized that the Wemme Trust specified work with "wayward girls" only.

In February of 1975, the Hospital Advisory Council petitioned the state to allow White Shield to affiliate with University Hospital North and a six month trial period was approved. The new affiliation program was to include wed and unwed mothers with problem pregnancies. The affiliation provided that when a White Shield resident was near delivery, she could be transported to University Hospital North to deliver her child, to return twenty-four hours after the birth of the child, providing there were no complications during labor or delivery. The affiliation gave University Hospital North the option to hospitalize maternity patients with problem pregnancies at the Wemme Maternity Hospital for extended periods of time to allow University Hospital North to use the vacant maternity beds for patients just prior to or immediately after delivery. A "problem" pregnancy would include any pregnant woman needing bed rest 
or special attention any time during the pregnancy because of edema, placenta previa and various other complications. A certified Nurse-Midwife trained at Yale University would screen and care for patients during the prenatal/delivery/ postpartum care. The University Hospital North and a designated doctor would be back-up.

This new affiliation was felt to be a better use of White Shield Home and the Wemme Hospital facilities, better medical service, and offer closer communication between patient and physician, without an increase in financial obligations. In July of 1975, the affiliation was finalized. In September the Medical Committee reported that the medical aspect of the affiliation was working well, however, White Shield Hospital was not caring for many patients from the University, though more use was expected in the future.

White Shield Home statistical highlights for 1973 are shown in Table V. 44

\section{TABLE V}

STATISTICAL ANALYSIS, 1973

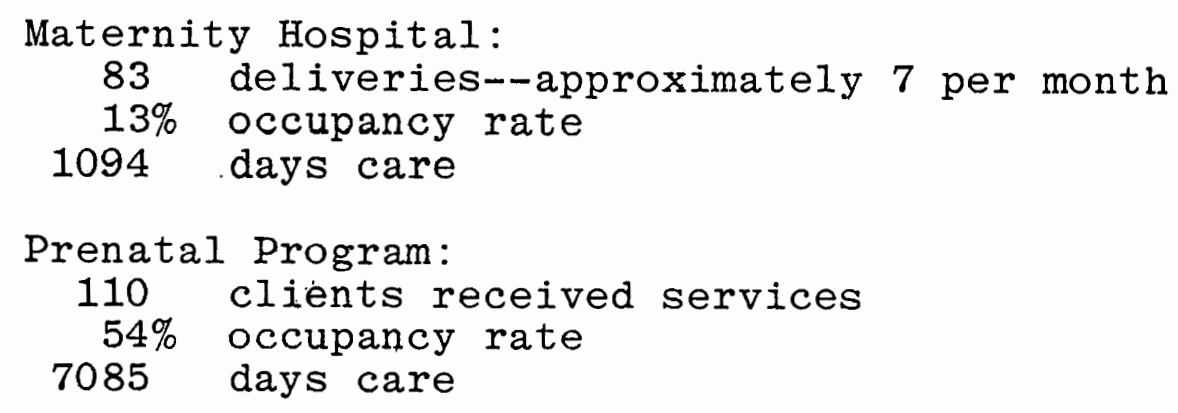


TABLE V, continued

STATISTICAL ANALYSIS, 1973

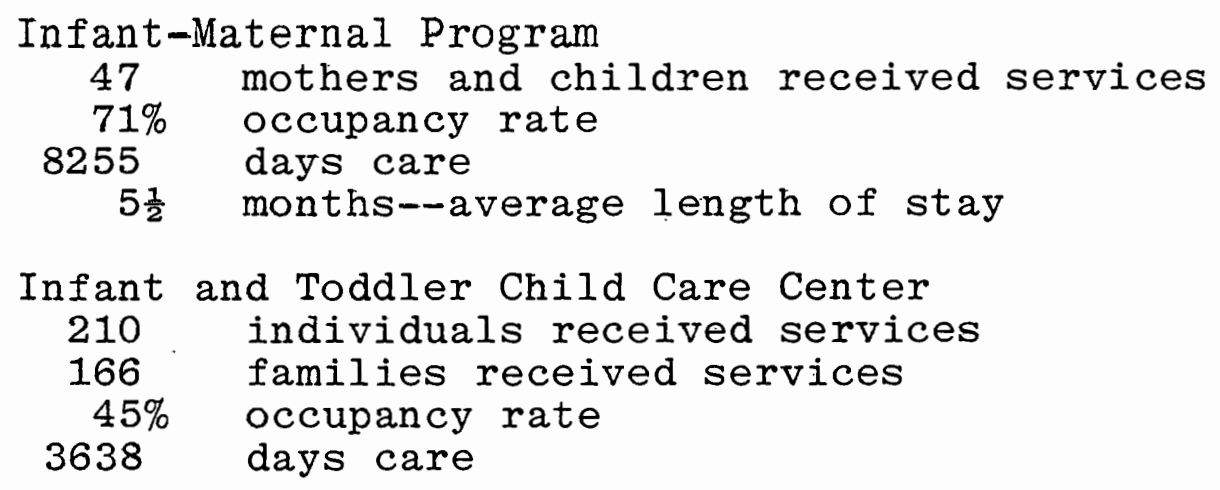

School :

102 students received 1034 hrs. supervised study 6 high school graduates

1 college graduate/teachers certificate

1 General Education Degree (GED)

Supportive services in 1973 included these: social service counseling, recreational and group therapy, psychological consultation, religious life program and health services.

In 1974, White Shield staff included seven employees in administration, nine in the residence, ten in Central Services, six in the Hospital, six in Social Services, and ten in the Child Care Center, for a total of forty-eight staff members.

In July of 1971 , there was a reorganization in the State Department of Human Resources which affected White Shield. At this time the State of Oregon Children's services Division was established and the Welfare Departments were headed by one person. The Council Meeting Minutes 
stated the members' concern in this manner:

This constitutes a major shake-up in the State of Oregon and no one can seem to get any definite answer. We are particularly concerned about referrals to us for 'Purchase of Care', which is the way we can best finance the program. 45

This concern was given no further mention in council meeting minutes, but reflected the confusion aroused while the State was reorganizing the delivery of services through the development of the Childrens Services Division.

A reorganization of the administration at white Shield also occurred in the early seventies. In September of 1973, the administrator of White Shield, Major Maynard, adopted a new organizational system for administration of the White Shield Home. She formed what she called the Management Team, comprised of the head of each department (i.e., hospital, residence, social service, etc.), for the purpose of providing a team approach to decisions regarding management and programming of White Shield Home. Major Maynard diagrammed this "Management Team" in the form of an umbrella. A revised copy of her diagram accompanies this paper in Appendix I. The purpose of this newly organized Management Team was to more efficiently and effectively receive input from each department for a consistent team approach in the delivery of services. This organizational structure is still in effect at White Shield Home today and is considered by most staff an effective and desirable approach for the management of the range of services provided at White Shield. 
According to the statistics gathered for this paper, the median age of White Shield Home clients between 1970 and 1975 was seventeen, the youngest of the sample was fifteen, the oldest was twenty-five. All members of the sample were Caucasian. About 22 percent of the sample for the seventies were from single-parent homes. About 44 percent released their children for adoption, a decline of 13.9 percent from the corresponding figure for the sixties. About 67 percent of the sample obtained state aid for receiving services at White Shield; a considerable drop from the 91.7 percent in the fifties and sixties. About 44 percent of the alleged fathers acknowledged paternity in the seventies. 


\section{CHAPTER V}

\section{HIGHLIGHTS AND SUMMARY IN TRENDS}

The greatest issue in the forties was in the merging and organization of the Salvation Army White Shield Home and the E. Henry Wemme White Shield of Portland. The studies and reports completed in the forties dealt largely with organizing the delivery of services.

Since little information was provided for the fifties, it is difficult to discern highlights of that period, which possibly reflects a calm, post-transitional period. However, that cannot be concluded simply because of lack of material. Some new committees were established by the Hospital Advisory Board in the fifties, for improved organization of the Board. The sixties were complicated and active for White Shield Home. The Home was rapidly becoming over-crowded, which generated the need for expansion. The Home had managed to fill all possible space until it could accommodate no more. The only option was to expand the facility. Much time was spent pursuing possibilities, which finally resulted in the construction of the residence building and the chapel/school building. This allowed for increased services that White Shield could provide. The lack of adoptive homes also had to be dealt with in the sixties. 
Other important events of the sixties included the issuance of the non-discrimination policy, the increased services of the school program, the public relation concerns, and the extensive involvement of the White Shield Women's Auxiliary.

The early seventies were also busy and productive years for White Shield. As a result of the liberalized abortion law in Oregon, and the changing values of society, the occupancy rate declined rapidly early in the seventies. This rapid decline created a serious crisis in the survival of. White Shield and negotiations took place in order to keep the agency alive. Many options for use of the facility were researched until a needs assessment of the community gave rise to the Infant-Maternal Program, which in turn gave rise to the Infant and Toddler Child Care Center.

A second crisis in the seventies occurred when Emanuel Hospital discontinued its medical contract with White Shield. White Shield desperately searched for a manner in which to provide its residents with consistent and convenient medical service. Out of this crisis arose the affiliation with University Hospital North, which still exists.

Other highlights of the seventies include, the organization of the Public Relations Committee of the Board, the reorganization of the staff at White Shield (The Management Team concept), and continued involvement of the Women's Auxiliary . 
The staffing patterns at White Shield have varied over the years. The need for increased staffing has been ongoing since the $1940^{\prime} \mathrm{s}$, and particularly during the $1960^{\prime}$ 's when the facility was expanded and the capacity increased. In June of 1945, the staff at White Shield and Wemme included one superintendent, one assistant superintendent, two Salvation Army officers, one caseworker, one cook, one bookkeeper, one hospital assistant, three nurses, three attendants and four house officers, for a total of eighteen staff members. In 1954, White Shield staff included six Salvation Army officers, three registered nurses, two caseworkers, and nine employees, for a total of twenty staff members. In 1974, the White Shield staff included seven administration employees, six hospital attendants, six social workers, and ten child care staff for a total of forty-eight staff members. This increase from 1954 to 1974 reflects the expanded facility; the forty-eight staff members in 1974 excludes school and kitchen personnel.

In regard to occupancy trends, the forties reflect a busy time for White Shield. It was necessary to minimize a girl's length of stay in order to serve additional clients. The need for expansion was an issue in the forties due to the low capacity, and again an issue in the sixties. Early in the 1950's, there was some concern about low occupancy in several of the Salvation Army Homes including White Shield, but before the situation could be analyzed in regard 
to the need for services, the pendulum began to swing upward again until in the sixties White Shield became overcrowded. Early in the sixties, more bed space was created wherever possible until it was no longer feasible to provide for more residents. The need for expansion became so great that a new residence and chapel/school building was constructed in the late sixties.- Due to the liberalized abortion laws and the changing values of society, the occupancy rate dropped drastically in the early 1970's. Gradually, it became more socially acceptable for young women to bear and raise children out of wedlock so that the need for one to go to a home such as White Shield to maintain confidentiality decreased.

As of 1977, there appears to be another gradual swing toward an increasing population at White Shield as well as other homes run by the Salvation Army. However, the reasons listed for coming to White Shield are very different than in earlier times. The reasons have shifted from confidentiality to the need to pursue goals, such as attending school or work. This increase in population and shift toward pursuing educational and vocational goals also reflects society's changing ideals, as education and career are now looked upon with high regard. With increased career opportunities and job mobility for women, even the younger women are beginning to set long-term career goals for themselves. 
White Shield Hospital Advisory Council projects that with increased public awareness the population will again rise in the late 1970's and early 1980's.

There were continuous questions regarding the Hospital at White Shield since its beginning. Early in the forties there was a suggestion to discontinue deliveries at White Shield as the delivery facilities were in need of repair. However, deliveries continued in the main building until 1951 when a new hospital was added onto the administration building. Deliveries were held in the new hospital throughout the fifties and sixties. In September of 1972, when Emanuel Hospital discontinued its contract with White Shield, another arrangement had to be made for deliveries. Soon after, the affiliation with University Hospital North was completed and girls were transferred there to deliver, which is the current procedure.

According to the statistics gathered for this study, a few trends can be discerned. In regard to age, the percent of the samples for each ten year period showed an increase of younger clients from the forties through the seventies. In the forties, 8.3 percent of the sample were below age sixteen; in the fifties and sixties, 16.6 percent were below sixteen; but in the seventies, 22.2 percent were below sixteen. The other figures in regard to age over the years show no patterns. (See Appendix J.) 
In regard to race, the results show 91 percent in the forties and fifties were Caucasian, while in the sixties and seventies, the sample shows 100 percent Caucasian clients.

The listings of occupations held by clients revealed most in low-paying jobs throughout the years. This most likely reflects the age of clients, as one is not usually established in a career before mid-or late-twenties; and, in fact, before the late sixties and early seventies, women were much less inclined to pursue a career.

Gradually, clients appeared to be less likely to come from single-parent homes. In the forties, 58.3 percent came from single-parent homes; 41.6 percent in the fifties; and 33.3 percent were from single-parent homes in the sixties and seventies. However, the percentages do not show a highly significant decrease. (See Appendix K.)

In regard to percentages of infants released, no pattern can be discerned from such a small sample. In the same respect, it is not possible to see a pattern in agency to which the child was released. The agencies used were as follows: Catholic Charities, Boys and Girls Aid Society, Waverly, Albertina Kerr, and only a couple of private adoptions .

There appears to be a significant increase in the use of state aid in the 1950 's. The percentage went from 33.3 
percent in the forties to 91.6 percent in the fifties and sixties and down to 66.6 percent in the seventies. (See Appendix L.)

A slight increase in percentage of acknowledgement of paternity by the alleged father appears over the years, from 25 percent in the forties to 33.3 percent in the fifties, to 41.6 percent in the sixties and to 44.4 percent in the seventies.

There appears to be no pattern in age of the father according to the statistics gathered, although generally they are older than the girls.

The percentages of Caucasian fathers is slightly lower over the years than it was for the women. In the forties, 66.6 percent of the alleged fathers were Caucasian; 75 percent in the fifties; 83.3 percent in the sixties; and 44.4 percent in the seventies. The other fathers were Chicano, Black and Spanish. Only tentative conclusions can be drawn as girls were not always willing to divulge this information. A listing of the occupations of the fathers reveal few in high paying, high status jobs. The average length of stay for a girl in the forties was 78.75 days; increased in the fifties to 89.41 days; decreased in the sixties to 61 days; and increased greatly in the seventies to 93.3 days. The low average in the sixties could be attributed to the beginning of the 
out-patient program in which many girls took part. The high average in the seventies could be attributed to the development of the Infant-Maternal Program in which girls resided at White Shield for more extended periods of time. 


\section{CHAPTER VI}

\section{CONCLUSIONS}

Certain generalizations can be made from this study, some of which may throw light on more general situations in which organizations are adjusting to changing pressures.

In spite of White Shield's nearly constant transition over the years, the comprehensiveness of services has expanded to provide a total living experience for residents. They are now not only provided with room, board, and medical services, but may reside in the home with their child, put their children in day care, go to school or pursue other goals and interests without necessarily leaving the White Shield campus. If a resident has a special need that White Shield cannot meet. (such as vocational training), a White Shield social worker plans with the resident to arrange for her to receive services from outside agencies. Viewing each resident in a total life situation is a philosophy that the White Shield staff has adopted over the years. This is reflected in the decisions to expand services in the directions shown in the preceding pages.

Consistency in the delivery of services has evolved at White Shield and today is considered an important and essential quality. The development of the Management 
Team, described previously, has had a great impact on the consistency among the various departments. This concept allowed for improved communication among departments in working toward the best interest of the client. The social service staff has encouraged all staff members to recognize their role as positively influential in the lives of clients. Child care workers have recently become recognized as significant and influential persons, not only at White Shield Home, but in residential settings throughout the field of social work. Child care workers are in direct contact with residents twenty-four hours a day and provide continuous role modeling. Recognizing the importance of consistency and coordination of services has allowed staff members appreciation of communication among departments.

The changes White Shield Home experienced throughout the years led to certain generally felt ideals, notably consistency. It is interesting, from the point of view of change mechanisms, to take an overview of the transitions of White Shield while they were occurring and notice the reasons White Shield made major modifications and additions in programming, administration, physical setting and staffing patterns. Changes in laws, such as the liberalization of abortion, as well as changes in societal values reflected in desires and needs of clients, have imposed necessary adjustments on White Shield. 
White Shield on one hand needed to concern itself with survival as an agency. During times of drastic diminution of occupancy, financial considerations were utmost and White Shield began to search for options that would draw clientele to the program. The pressures to stay alive became acute. Closure of White Shield would be seen as a tremendous loss for the Salvation Army as well as posing unemployment problems for staff members.

White Shield, on the other hand, adjusted and developed programming to accommodate the community at large. In times of uncertainty, White Shield would obtain a needs assessment of the community to determine how the facility could best serve community demand. Serving the community appropriately was important for White Shield in establishing itself as a helping agency that responded to societal demand.

White Shield has been striving throughout the years to find its place in society, and as an agency with a desire to provide social services to those in need.

This paper has demonstrated how White Shield, over the years, has shown its flexibility, its urge to survive as an agency serving its community and its willingness to serve humanity. 


\section{SOURCES CITED}

Some references are without known dates or publishers, but may be found in the files of The Salvation Army White Shield Home.

1. Spencer, Omar C., "E. Henry Wemme Endowment Fund," Booklet, Sweeney, Krist and Dimm, (Portland, Oregon), p.3.

2. Ibid., p.3.

3. Ibid., p.7.

4. Ibid., p.8.

5. Ibid., p.II.

6. Ibid., p.16.

7. Ibid., p.20.

8. Ibid., p.21.

9. Ibid., p.23.

10. Council on Social Agencies, "Council on Social Agencies Report, Salvation Army White Shield Home, Salvation Army Wemme Home," (June 8, 1945), p.I.

11. Ibid., pp.1,2.

12. Ibid., pp.2,3.

13. "Services Provided by Agencies in Multnomah County to Unmarried Mothers: and their Infants," Agency Function Study, p.I.

14. Child Welfare Review Committee, "Salvation Army White Shield and wemme Homes Tentative Recommendations," (May 14, 1946), p.1.

15. Ibid., pp.1,2. 
16. Portland Council of Social Agencies, "Report on Child Welfare Agencies, 1945-1946," (May 31, 1946), pp. 41,42 .

17. The Salvation Army Women's Social Service Department, "Ten Year Report of Services for Calendar Years 1945 thru 1954," (January 5, 1956), p.9.

18. Ibid., p.12.

19. Ibid., p.15.

20. Hospital Advisory Council, "Board Meeting Minutes," (December 16, 1959).

21. Ibid., (January 4, 1968).

22. Ibid., (January 5, 1961).

23. "Report and Recommendations to Mr. Randall S. Jones, Chairman, Members of White Shield Home and Hospital Advisory Council," p.1.

24. Ibid., p.1.

25. Ibid., p.2.

26. Hospital Advisory Council, "Board Meeting Minutes," (September 24, 1968).

27. Ibid., (September 24, 1968).

28. Ibid,, (November 7,1963 ).

29. Ibid.,Commissioner Glen Ryan, Speaker, (March 3, 1965).

30. "Notes on Salvation Army Facilities Tour with Captain Jack Grable, 2/16/66: White Shield Home and Wemme Memorial Hospital for Unwed Mothers," (also Appendix D) .

31. Hospital Advisory Council, "Board Meeting Minutes," (March 3, 1966).

32. Ibid., (June 18, 1969).

33. Ibid., (April 9, 1970).

34. Helen Grier, Director of Social Service Department, White Shield Home, "Report of Current Service to Hospital Advisory Council," (November 12, 1970), p.I. 
35. Ibid., p.2.

36. Hospital Advisory Council, "Board Meeting Minutes," (April 8, 1971).

37. Ibid., (April 8, 1971).

38. Ibid., (August 12, 1971).

39. Ibid, (September 9, 1971).

40. Letter to various community agencies, Description of Programs, White Shield Home, (August 7, 1972), also Appendix G.

41. Hospital Advisory Council, "Board Meeting Minutes," (June 29, 1972).

42. Ibid., (October 19, 1972).

43. Ibid., (October 19, 1972).

44. Ibid., (April 11, 1974).

45. Ibid., (October 21, 1971). 


\section{APPENDICES}

A The Wemme Trust

B Outline to Define Agency Function - Child Caring Agency

C The Salvation Army Policy on Non-discriminatión

D Notes on Salvation Army Facilities Tour

E Comparative Statistics - Ten Year Period (1954-1963)

F Tri-County Community Council - Report of the Unwed Mother Study Committee - 1972

G Letter - Description of Programs at White Shield Home (1972)

H Report on Services at White Shield Home and Wemme Maternity Hospital - July 14, 1973

I The Management Team Approach - 1973

$\mathrm{J}$ Age Distribution By Decade

K Percentages From Single-Parent Homes By Decade

L Percentages Receiving State Aid By Decade 


\section{APPENDIX A}

\section{THE WEMME TRUST}

It would perhaps be sufficient to summarize the provisions of the trust which resulted in the formation of the E. Henry Wemme Endowment Fund, but it is believed that a quotation of the exact provisions of the trust should be given. However, it should be said, generally speaking, that it was the purpose of Wemme to build, equip and have operated a maternity home of unfortunate and wayward girls. The maternity home was to be operated as a lying-in hospital.

Coming then to the provisions of the trust as created by Wemme, the language which he used in his will is as follows:

Sixth: I give, devise and bequeath unto H.A. Weis, Jessie M. Carson and J.J. Cole and their successors, Lots 1,4,5, and 8 in Block 53 in Couch's Addition to the City of Portland and also Lots 1 and 4 and the south 20 feet of Lot 5 in Block 9 of Couch's Addition to the City of Portland and the south 120 feet of Block 72 in East Portland, now a part of Portland, and all now being in the City of Portland, Multnomah County, State of Oregon, to be in trust, however, by said H.A. Weis, Jessie M. Carson and J.J. Cole and their successors for the use and purposes herinafter set forth as follows: Said trustees and their successors shall have power and authority to hold, manage, improve, repair or lease said property or any part thereof without any other authorization than that hereby given, and shall collect all rents issues and profits first pay all taxes, assessments and charges of whatsoever kind or nature lawfully made against said property, or any part thereof.

My said trustees shall immediately after my death cause to be formed a corporation under the name of "E. Henry Wemme Endowment Fund" under and by virtue of the laws of the State of Oregon, providing that 
the duration of said corporation shall be perpetual, that its principal office and place of business shall be in the City of Portland, County of Multnomah and state of Oregon, with a capital stock to be determined by my trustees, not to exceed, however, the reasonable value of the property hereinbefore devised to my trustees, at the time of such incorporation, and incorporated for the purpose of buying, owning, holding, managing, improving, mortgaging and leasing the real property hereinbefore devised to my trustees, and for the purpose of conducting a maternity home or laying-in hospital for unfortunate and wayward girls in the City of Portland; Multnomah County and State of Oregon.

My said trustees shall jointly subscribe for all of the capital stock of said corporation, and shall thereupon complete the organization of such corporation and cause such action to be taken by it that it shall purchase of my said trustees all of said property hereinbefore devised to my trustees, and in payment therefor, issue its capital stock to my said trustees, jointly, and thereupon said trustees shall by good and sufficient conveyance or conveyances grant, bargain, sell and convey to said E. Henry Wemme Endowment Fund a corporation, all of the real property hereinbefore devised to said trustees, and thereupon the capital stock of said corporation of E. Henry Wemme Endowment Fund shall be issued to said trustees jointly in one certificate, which capital stock witnessed by said certificate shall be held in trust by said trustees, and disposed of by them as hereinafter directed.

Immediately upon the completion of the organization of said E. Henry Wemme Endowment Fund, and the transfer to said corporation last mentioned of the property herein devised to my trustees, then and thereupon said corporation shall have the right to borrow a sum of money not to exceed $\$ 75,000.00$ upon the promissory note of said corporation, and to secure the payment of such promissory note by mortgage executed by it covering Lots 1 and 4 and the south 20 feet of Lot 5 in Block 9 of Couch's Addition to the City of Portland, in Multnomah County, State of Oregon, said promissory note and mortgage shall contain such provisions and conditions as may be determined and agreed upon by said corporation and the person, firm or corporation from whom it may secure such loan. 
After securing money on the mortgage hereinbefore provided to be executed by it the said E. Henry Wemme Endowment Fund shall proceed to purchase suitable real estate as a site for a maternity home for unfortunate and wayward girls, and shall construct thereupon a suitable home for the reception, accommodation, care, treatment and comfort of unfortunate and wayward girls who may be in need thereof, and shall furnish, equip and maintain such maternity home without cost or charge to the inmates thereof, but shall use the rents, issues and profits arising and issuing out of the property owned by said E. Henry Wemme Endowment Fund, in maintaining, furnishing and equipping said maternity home, and in caring for and providing for the inmates thereof, making a provision, however, should the said corporation deem it necessary, for a sinking fund from such rents, issues and profits to pay out thereof, when it shall have become due said note given by the corporation as hereinbefore provided. Said maternity home shall be known as the White shield of Portland, Oregon, and the inmates shall be admitted thereto irrespective of religion or nationality.

Said corporation by and through my said trustees who shall constitute the board of directors thereof, shall after the construction of said home open and thereafter conduct the same for the accommodation, care and keeping of unfortunate and wayward girls as a lying-in hospital without charge therefor.

In case of death, resignation or permanent inability of any or either of my said trustees to act as such trustee or trustees, then and in that event the successor or successors of my trustees who may die, resign or be permanently disabled from the performance of the duties as trustee hereunder, and such successor shall have the right in the same way to appoint their successors and so it shall continue, and a majority of the trustees shall have the right to exercise full power and authority under and by virtue of the provisions of this my Last Will and Testament.

Upon the expiration of three years from and after my death I direct that my trustees transfer to the different churches of the Church of Christ Science of Portland, Oregon, authorized and chartered by the 
head Church of Christ Science known as the Mother Church of Boston, Massachusetts, all of the capital stock of the said E. Henry Wemme Endowment Fund in equal parts, to be theirs forever, for their own respective uses and benefit and without any charge or trust reserved to my estate of whatsoever kind or nature, and thereupon my trustees and their successors shall be considered as having completed their duties hereunder and discharged.

I hope, however, this is not directory, but merely a suggestion that the maternity home constructed as hereinbefore provided shall be continued by said corporation, E. Henry Wemme Endowment Fund, perpetualiy, and forever, but I do not make this binding upon said Church of; Christ Science, or upon said E. Henry Wemmed Endowment Fund, a corporation, for the reason that I have implicit faith and confidence in the Church of Christ Science and believe that they will be perpetual and I realize the inability of one now living to determine what in the future might be the greatest need and benefit: to suffering humanity, and therefore I have given absolutely and without reservation all of the stock of said corporation of said E. Henry Wemme Endowment Fund, to said Church of Christ Science believing that they will expend the rents, issues, and profits and all the proceeds of the said E...Henry Wemme Endowment Fund in a manner so as to create the greatest relief for the greatest number of suffering humanity.

Tenth: My said trustees shall make a statement of their receipts and expenditures annually, and file the same with the person performing the duties now performed by the clerk of the court having jurisdiction of probate matters in Multnomah County, provided such officer will receive such report, which statement will be a public record and subject to inspection by all parties. And I hope that said E. Henry Wemme Endowment Fund, a corporation will continue to file such report after it shall have come into possession of the property herein directed to be conveyed to it.

Note: Quoted from Omar C. Spencer, E. Henry Wemme Endowment Fund, Booklet, Sweeney, Krist and Dimm, (Portland, Oregon), pp. 8-11. The Wemme Trust executed as part of E. Henry Wemme will on December 27, 1913. 


\section{APPENDIX B}

OUTLINE TO DEFINE AGENCY FUNCTION - CHILD CARING AGENCIES

NAME OF AGENCY

Please check:

$$
\begin{aligned}
& \text { Is your agency public?_ Private? } \\
& \text { Is your agency non-sectarian? }
\end{aligned}
$$

The purpose of this outline is to study present agency function with present available staff, funds, and facilities. Questions as to whether you give a service, therefore, apply only to whether you are giving the specific service to a child at present, or could give it if asked today.

Please mark in accordance with each of the four groups below, where the mark suggested is applicable.

1. Mark "A" if you can serve all who apply.

Mark " $M$ " if you can serve most of those who apply.

Mark "S" if you can serve some of those who apply.

2. Mark "F" if the function described is a major one with your agency.

Mark "L" if the function described is a lesser function of your agency.

3. Mark "U" if you find there are still unmet needs for the service described regardless of the service you and others give.

4. Mark "E" if you can give emergency care in this field. 
OUTLINE TO DEFINE AGENCY FUNCTION - CHILD CARING AGENCIES, continued

I. (a) Do you give service to unmarried mothers?

At home?

In foster homes?

In institutions?

(b) Do you give service to their newborn infants?

At home?

In foster homes?

In institutions?

(c) Do you help unmarried mothers establish themselves with their child?

In a home? In a job?

II. (a) Do you place children for adoption? $0-5$ yrs $2-5$ yrs Over 5 yrs

(b) Do you supervise after adoption? 6 months 1 year

III. (a) Do you place children in boarding homes?
$0-5 \mathrm{yrs}$
$5-12$ yrs
Over 12 yrs
$0-5 \mathrm{yrs}$
$5-12$ yrs
Over 12 yrs
$12-15$ years
Over 15 years

(b) Do you place children in free homes?

(c) Do you place children in work homes?

IV. (a) Do you accept children for service who are:

$0-5 \mathrm{yrs}$ $5-12$ yrs Over 12 yrs

(b) Do you accept children for service in foster homes who are:

Catholic Jewish Protestant other

(c) Do you accept children for service in institutions who are:

Catholic Jewish Protestant Other 
OUTLINE TO DEFINE AGENCY FUNCTION - CHILD CARING AGENCIES, continued

V. Do you give long-time care to:

(a) Children of all races

(b) Where there are no special problems except economic

(c) Where there are medical problems

(d) Where mental development is retarded (moron or below)

(e) Where there are emotional or behavior problems

( $f$ ) Where there is delinquency

VI. Do you give short-time dependency care to:

(a) Children of all races

(b) Where there are no special problems except economic

(c) Where there are medical problems

(d) Where mental development is retarded (moron or below)

(e) Where there are emotional or behavior problems

(f) Where there is delinquency
In foster homes In institution

In institution with mother

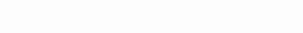


OUTLINE TO DEFINE AGENCY FUNCTION - CHILD CARING AGENCIES, continued

VII. Do you give service to children for a period immediately after their return home from your institution or foster home?

Do you give service to children for a period immediately after their return home from institutions or foster homes not under your auspices?

VIII. Do you give service to children in their own homes without other placement?

(a) Where the child has medical problems

(b) Where the child has problems of mental retardation

(c) Where the child has emotional or behavior problems

(d) Where the child is delinquent

(e) Where the parent has emotional problems affecting the child

(f) Where the child needs day care

(g) Where the parent has primarily economic problems

\begin{tabular}{|c|c|c|}
\hline $\begin{array}{c}\text { Any } \\
\text { Children }\end{array}$ & $\begin{array}{l}\text { Previous } \\
\text { Wards }\end{array}$ & $\begin{array}{c}\text { Other Iimitations } \\
\text { (State) }\end{array}$ \\
\hline
\end{tabular}
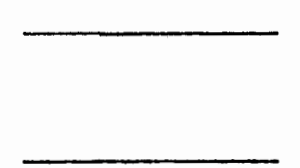
OUTLINE TO DEFINE AGENCY FUNCTION - CHILD CARING AGENCIES, continued

IX. Do you give service to out of town agencies?

Does your agency participate in public education?

Does your agency participate in legislation?

List any other services

Comments, additions or explanations you feel are needed:

Submitted by: Stuart Stimmel

J. Warrington Stokes

Helen Exner, Secretary 


\section{APPENDIX C \\ THE SALVATION ARMY POLICY STATEMENT \\ ON NONDISCRIMINATION}

As an agency dedicated to community service, we affirm the policy and practice that minority groups participate in the affairs of the organization without regard to race, creed, color or national origin.

\section{STATEMENT OF POLICY}

It is the policy of The Salvation Army to conduct its operations and extend its services without racial discrimination in any form. This policy applies to persons serving on the Board and on Committees, and to persons employed in the staff organization. Operating without discrimination means that:

No person be excluded from service or from serving because of race,

there be no segregation of those served or serving, on the basis of race,

there be no discrimination with regard to employment, assignment and promotion of staff,

agency governing and advisory bodies are open to representation from all racial segments of the public,

inter-racial understanding be promoted.

Affirmed by The Salvation Army.

Hospital Advisory Council Chairman

Officer responsible for

institution or department 
NOTES ON SALVATION ARMY FACILITIES TOUR WITH CAPTAIN JACK GRABLE, 2/16/66, WHITE SHIELD HOME AND

WEMME MEMORIAL HOSPITAL FOR UNWED MOTHERS

This $2 \frac{1}{2}$ story brick-frame home is located on a $4 \frac{1}{2}$-acre, wooded sițe at $2640 \mathrm{~N}$.W. Alexandra Street, Portland, Oregon. Built in 1915, it is designed to accommodate 46 girls, but by crowding girls into the top floor area under the slanting roof, it had 52 residents the day of our visit, plus a waiting list approximating the facility's capacity, i.e., about 50 .

The SA staff, headed by Superintendent Major Pauline Snider, includes Captain Sue Miller, Lt. Murriel Nash, and Lt. Carol McCall, and a civilian staff of 27 , including 4 full-time registered nurses, 2 licensed practical nurses, 3 nurses aids, 4 part-time registered nurses, and 2 case workers. Three teachers are supplied (in addition to the 27 employees) and paid by the State Department of Education. The two room school section can accommodate only 26 girls taking elementary and secondary classes for credit.

The medical staff is headed by $\mathrm{Dr}$. Oliver Nisbet as Chief of Staff. The Obstetrical Staff is headed by Dr. Duncan R. Neilson and Dr. John A. May as the Chief Pediatrician. There are eight consultants in addition to the Senior Resident Doctor on Service. 
During 1965 a total of 283 girls, including 240 teenagers, were cared for at the White Shield Home. The average stay is 63 days. Girls, 18 years of age and older, may participate in the foster wage-home program.

The day we were there, the Wemme hospital and nurseries were vacant (two mothers and babies discharged earlier that day), but 26 girls were "expecting" momentarily.

Girls (or their relatives) able to pay all or part of their costs in residence are encouraged to do so, but those without funds are admitted anyway. Total cost of care for Oregon girls in 1965 was $\$ 117,893.65$, of which $\$ 36,416.29$ was paid by relatives or girls able to work outside part time. These girls were given 14,154 days of care in 1965; their babies being given 964 days of care.

Approximately $75 \%$ of the girl mothers (including an occasional sub-teenager) place their babies out for adoption through five private adoption agencies and Public Welfare; $25 \%$ elect to keep their children.

Two nurseries for babies, and one delivery room, one labor room, a clinic room, and four recuperation rooms are part of the facilities provided in the Wemme hospital wing. There is a Senior resident doctor in obstetrics on a rotation basis each 6 months from Emanuel Hospital, plus a staff of consulting doctors who contribute their time. An outpatient clinic is operated once a week. 
Girls in White Shield (one of 37 Salvation Army homehospitals for unwed mothers) are assigned to regular household tasks, including work in the kitchen, dining room and laundry and maintenance of their own rooms. They also attend school, engage in arts and crafts projects, planned leisure time activity and have access to the library and recreation room with its TV and piano.

Emergency dental service and a "beauty bar" are also available.

Girls in White Shield, with their common problems, represent a good cross section of poor to wealthy families. They come from every county in Oregon (except Grant and Lake counties in 1965) and from 17 other states (in 1965) plus one girl from Bulgaria.

Out-of-state girls and parents paid $\$ 14,511.64$ of the $\$ 28,336.48$ total cost of care last year. These out-of-state girls were given 3,483 days of care for the year, and their babies 236 days' care.

The state of Washington provides more unwed mothers for White Shield Home care than any state outside Oregon. California ranks second, Alaska (with only 8 beds in its Salva-. tion Army home for unwed mothers) is third. Idaho (part of the Oregon division) is fourth and Nevada fifth.

The relatively high out-of-state patient load is accounted for by the fact that many girls and their families prefer to utilize out-of-state facilities--as far away from home and adverse publicity as possible. 
Last year 119 White Shield girls came from the MultnomahClackamas-Washington tri-county area, 109 from the balance of Oregon counties.

Obvious Needs at White Shield Home

While White Shield Home is attractive, homelike and beautifully clean and well managed, it is woefully inadequate in size and facilities.

It is overcrowded. It represents a fire hazard, especially on the top floor despite automatic sprinklers. Its two-room school, its dining room, and its reception and conference rooms are in drastic need of expansion. Its laundry equipment, plumbing and heating equipment are antiquated and overloaded. Its reception and conference rooms are virtually non-existent. Its chapel is makeshift at best. Its staff, while able and dedicated, needs more work room, better facilities and some strengthening, particularly in the nursing and social worker areas. Only its Wemme hospital wing appears adequate for further expansion and use. This explains why a $\$ 300,000$ expansion and rehabilitation program for White Shield Home is imperative, if the obvious and expanding needs of unwed mothers of Oregon, Idaho and other states are met. 


\section{APPENDIX E}

COMPARATIVE STATISTICS - TEN YEAR PERIOD (1954-1963)

E. Henry Wemme Memorial Hospital - Portland, Oregon (Broken down into $5 \mathrm{yr}$. periods for comparison)

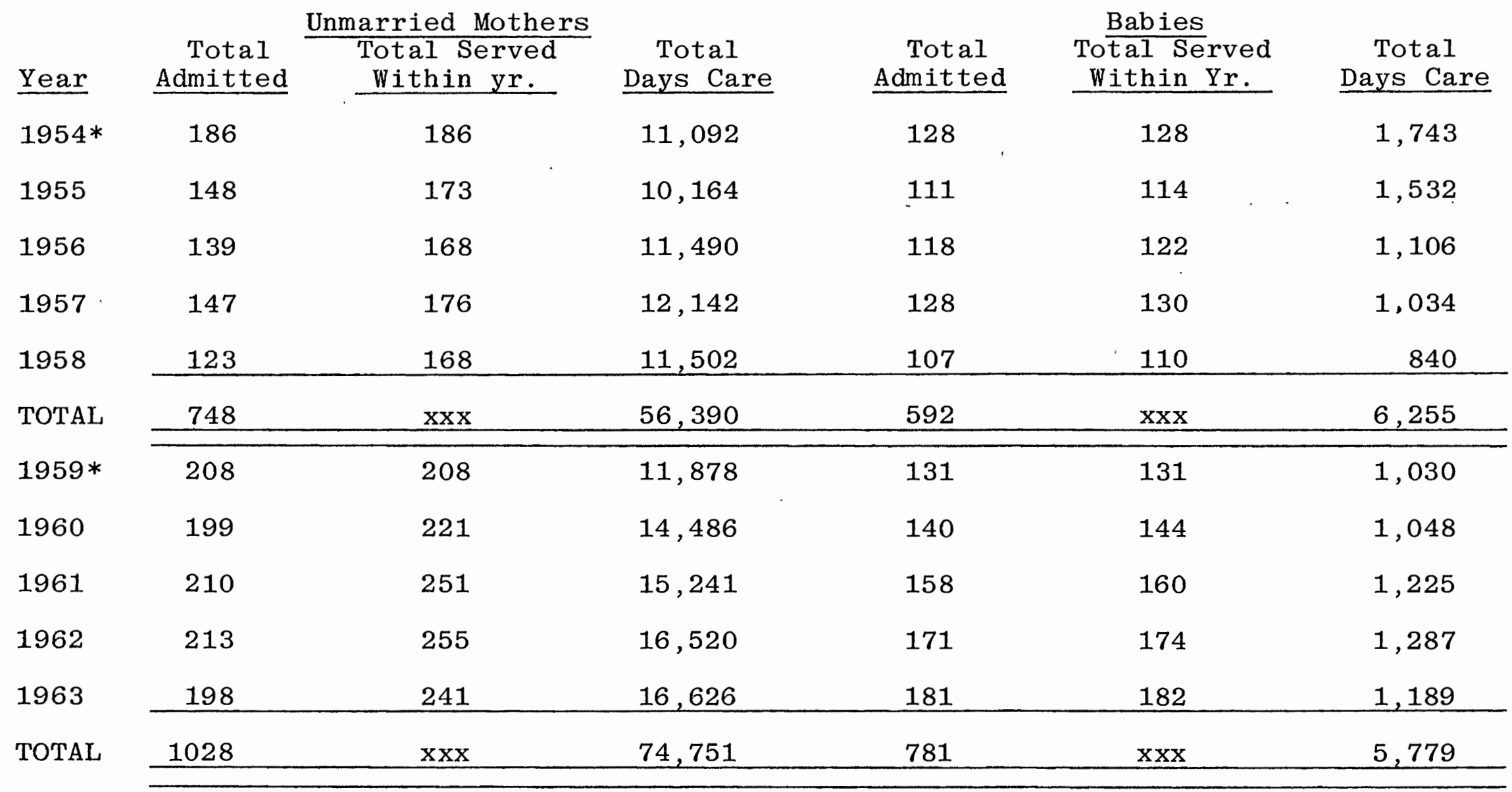

(*These totals include those carried forward from the previous year) 
COMPARATIVE STATISTICS - TEN YEAR PERIOD (1954-1963), continued

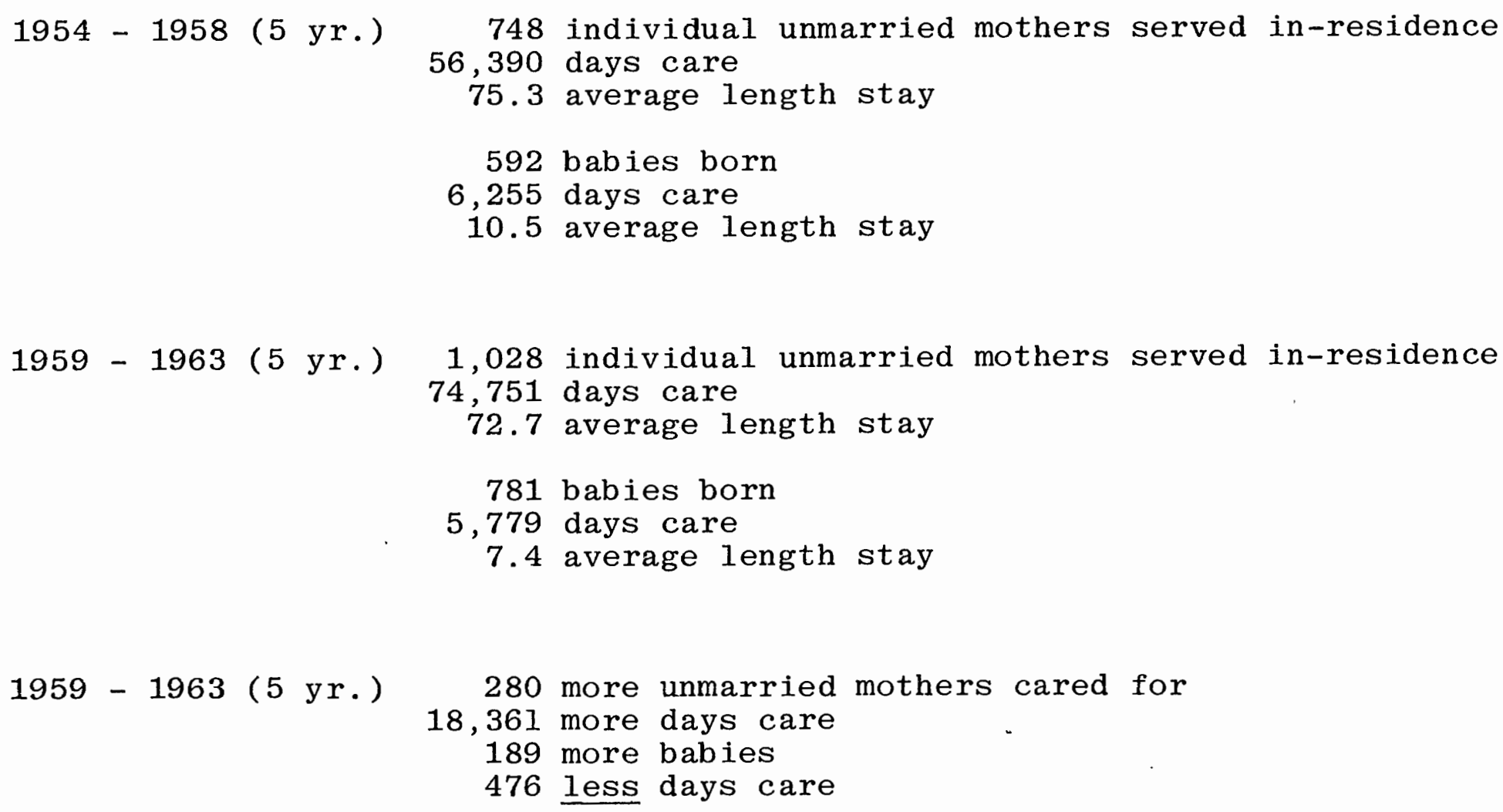




\section{COMPARATIVE STATISTICS - TEN YEAR PERIOD (1954-1963), continued}

The Salvation Army White Shield Home \&

E. Henry Wemme Memorial Hospital - Portland, Oregon

OCCUPANCY RATE

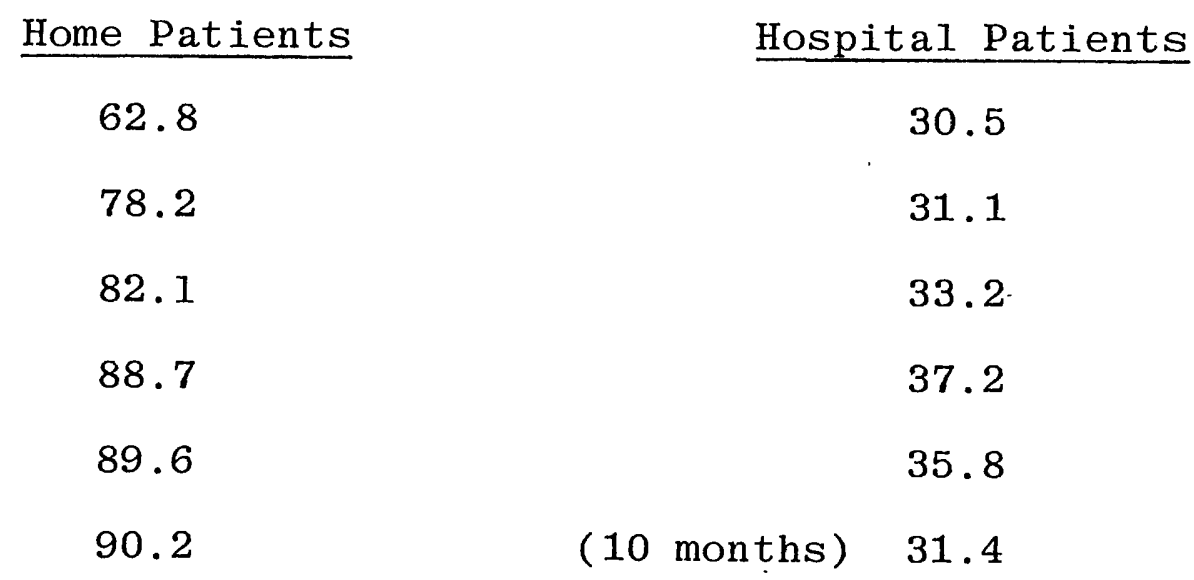




\section{APPENDIX F \\ TRI-COUNTY COMMUNITY COUNCIL REPORT OF THE UNWED MOTHER \\ STUDY COMMITTEE - 1972}

PURPOSE The study was undertaken at the request of the Salvation Army. Faced with a decline in a demand for services at White Shield Home, the Salvation Army asked that the TriCounty Community Council "undertake a full and comprehensive study covering the total services to unwed mothers that are currently being offered in the greater Portland area". The Salvation Army had undertaken it's own study which resulted in recommended changes in the program at White Shield Home, particularly for the postnatal care of mothers and their infants.

The Tri-County Community Council has a long range plan to review all fields of service which will cover, at a minimum, all U.G.N. agencies. For this reason, and in order to respond to the request of the Salvation Army and also because the Council was aware of marked changes in the field of unwed mother services, a committee was appointed:

1) to learn about the current picture in this field

2 ) to make recommendations about whether changes are necessary in the network of unwed mother services and

3 ) to recommend whether changes in services at White Shield Home are valuable and responsive to current and future community needs.

It should be noted that the Community Council has not done a study in the field of unwed mother services in recent years. The Council's most recent look at this field of service was in 1968 when the Priority study was updated. That study noted: "The number of births out of wedlock is increasing in the United States and in Oregon . . . . The number of unmarried have grown more rapidly than the facilities available to serve them . . . . Locally the agencies specializing in the care of unmarried mothers report that they are able to accept less than half the applicants coming to them. Some have long waiting lists and are reluctant to encourage more applications. Many mothers who need service do not apply." 
TRI-COUNTY COMMUNITY COUNCIL, continued

METHOD Data for this study was gathered through the Vital Statistic's section of the State Health Division and through a questionnaire sent to several agencies concerning changes in the volume of residential and out-patient services to unwed mothers. The Committee itself met with the director of the White Shield Home to learn about the agency's services and devoted one of its meetings to discussion with representatives of local agencies serving unwed mothers. In addition, individual committee members visited selected agencies.

The following agencies were contacted:

Albertina Kerr Homes, Boys and Girls Aid Society, Catholic Services for Children, Childrens Services Division Region I, Maternal and Infant Care Project of the State Health Division, Planned Parenthood Association of Portland, Volunteers of America, Waverly Childrens Home, Salvation Army White Shield Home and E. Henry Wemme Memorial Hospital. In Clark County Washington information was gathered from the Children's Home Society, the Department of Social and Health Services, The County Health Department and the Y.W.C.A. In addition, material was gathered from the Y.W.C.A. in Salem. Because Lane County Catholic Charities group home for unwed mothers, Villa Girard, is supported with United Good Neighbor funds through the Oregon United Appeal and is available to unwed mothers from the Portland area, this agency was also included in the study.

As can be seen from this list of agencies, the study did not attempt to review all of the services available in this community to unwed mothers.

FINDINGS

1. There are several factors that indicate a decrease in the demand for residential services for unwed mothers. The occupancy rate at White Shield Home was close to full in 1967 and 1968. It dropped to $80 \%$ in 1969 , to $61.5 \%$ in 1970 and $46.2 \%$ in 1971 .

Table I shows the number of unwed mothers served in selected local agencies in residential services for the years 1967 and 1971. In all areas of residential service including maternity home, group home, and foster family care there has been decreases in the number of unwed mothers served. 
TRI-COUNTY COMMUNITY COUNCIL, continued

\section{TABLE I \\ UNWED MOTHERS RECEIVING RESIDENTIAL SERVICE \\ IN SELECTED AGENCIES}

MATERNITY HOME

White Shield

GROUP HOMES

Boys \& Girls Aid Society

Catholic Services for

Children

Villa Girard

Total

FOSTER HOMES

Albertina Kerr Homes

Boys \& Girls Aid Society

Catholic Services for

Children

White Shield Homes

Total

TOTAL(Maternity, Group and Foster Homes)

$\begin{array}{lllll}1967 & \frac{1968}{307} & \frac{1969}{328} & \frac{1970}{531} & \frac{1971}{290}\end{array}$

27

28

28

29

39

\begin{tabular}{|c|c|c|c|c|}
\hline 27 & 28 & 30 & 10 & -- \\
\hline 30 & 30 & 27 & 30 & 20 \\
\hline & 86 & 85 & 69 & 59 \\
\hline
\end{tabular}

1

2

2

2

1

$141 \quad 123$

98

54

37

20

20

28

9

8

3

$\begin{array}{lllll}22 & 30 & 33 & 22 & 10\end{array}$

184

183

142

86

51

$\begin{array}{lllll}575 & 597 & 758 & 445 & 365\end{array}$

SOURCE: Data supplied by agencies in response to mailed questionnaire.

2. There has been a signigicant drop in recent years in both the number and rate of illegitimate births in Oregon. Table 2 shows that there were 2600 births out of wedlock in 1971 as against 3,000 in 1969. More significantly this table shows that the rate per thousand births for children born out of wedlock decreased from around 88 per thousand births in 1968 and 1969 to 78.7 per thousand in 1971. 
TRI-COUNTY COMMUNITY COUNCIL, continued

\title{
TABLE 2
}

\author{
ILLEGITIMATE BIRTHS IN OREGON
}

\begin{tabular}{|c|c|c|c|c|c|}
\hline & 1959 & 1968 & 1969 & 1970 & $\begin{array}{l}1971 \\
\text { est. }\end{array}$ \\
\hline ILLEGITIMATE BIRTHS & 1217 & 2831 & 3000 & 2912 & 2600 \\
\hline Rate per 1000 births & 33.2 & 88.1 & 88.7 & 82.4 & 78.7 \\
\hline Under 15 & $1.06 \%$ & $1.3 \%$ & $1.3 \%$ & $1.3 \%$ & na \\
\hline $15-19$ & 40.8 & 50.2 & 49.6 & 53.2 & $\mathrm{na}$ \\
\hline $20-24$ & 31.6 & 33.7 & 35.2 & 31.6 & na \\
\hline $25-29$ & 13.5 & 8.8 & 8.8 & 8.6 & $\mathrm{na}$ \\
\hline 30 - Over & 12.7 & 5.89 & 5.0 & 5.25 & $\mathrm{na}$ \\
\hline
\end{tabular}

3. Several factors have pläyed a part in reducing the number of children born out of wedlock. There is a general decline in birthrate, influenced in all age groups except possibly the youngest by the availability of and acceptance of contraceptives. With liberalization of state statutues, women who find themselves pregnant have available to them therapeutic abortion or, with changed and more accepting attitudes on the part of the public, the possibility of keeping their child with them whether or not they marry.

Table 3 shows the influence the liberalized abortion laws that became effective in Oregon in August 1969. The number of abortions in 1968 was 323 and jumped to 1407 in 1967 and to around 7,000 in both 1970 and 1971. The abortion rate per 1000 live births jumped from 10.0 in 1968 to 211.8 in 1971 .

4. Another indication of a shift in the decisions of girls who are pregnant out of wedlock is the report from all local adoption agencies that there are many less children available for adoption. For example, one agency completed 183 adoptions in 1966 but in 1971 completed only 41. 
TRI-COUNTY COMMUNITY COUNCIL, continued

\section{TABLE 3}

THERAPEUTIC ABORTIONS IN OREGON

\begin{tabular}{|c|c|c|c|c|}
\hline & 1968 & 1969 & 1970 & $\begin{array}{l}1971 \\
\text { est. }\end{array}$ \\
\hline ABORTIONS & 323 & 1407 & 7196 & 6995 \\
\hline Rate per 1000 births & 10.0 & 41.5 & 203.5 & 211.8 \\
\hline Under 15 & & $1.6 \%$ & $1.4 \%$ & $\mathrm{na}$ \\
\hline $15-19$ & & 33.6 & 33.3 & $\mathrm{na}$ \\
\hline $20-24$ & & 31.7 & 35.6 & $\mathrm{na}$ \\
\hline $25-29$ & & 13.8 & 13.6 & na \\
\hline 30 \& Over & & 18.3 & 16.1 & $\mathrm{na}$ \\
\hline $\begin{array}{l}\text { Unmarried (single, } \\
\text { divorced, separated) }\end{array}$ & & $75.6 \%$ & $77.0 \%$ & $\mathrm{na}$ \\
\hline
\end{tabular}

SOURCE: Vital Statistics Section of Oregon's Helath Division - Tables 2 \& 3 .

5. Even though there has been a drop in the demand for residential services, the agencies serving unwed mothers all note shifts in community and individual attitudes that call for adaptations and additions in their services. In fact, the agencies report that these adaptations require as much or more agency service time than was required in the past to service unwed mothers.

The adaptation needed in agency services is brought about by three factors.

1) The girls who are looking to agencies for services are much younger than those seeking similar services in the past. In the past those served were of various ages. Today those approaching the agencies are often under 15.

2) Because the girls are younger and because there are alternative courses of action that a girl can follow if she is pregnant out of wedlock, the agencies are called upon to do much more counseling. Very often 


\section{TRI-COUNTY COMMUNITY COUNCIL, continued}

unwed mothers are subject to peer pressure and family pressure to avail themselves of abortion. If this matter is to be fully considered, the agencies must involve both the girl and her family so that the decision reached is acceptable to all parties involved.

3) Attitudes about illegitimate pregnancies have changed. The attitude previously was one of concern to hide the girl from the stigma of an illegitimate pregnancy with encouragement for her to release the child for adoption. Now there is greater tolerance and acceptance of the illegitimate pregnancy and an accompanying encouragement, particularly from peers, for the unwed mother to keep her child whether or not she marries.

It appears to be a fact that many girls who do carry through their pregnancy out of wedlock, do now keep their children. For those mothers who keep their child the agencies are called upon to much mare in assisting her in learning how to be a parent and about child care and child health. Of course when these mothers are under 15, the need for such training is much more pressing. In many of these instances the living arrangement for the mother and her infant are fraught with additional problems that indicate the agency should remain in the picture to counsel the mother, her child and whomever she is living with. Often such young mothers living with their own family develop conflicts that can only be resolved by the young mother and her child moving away, yet if this is to be accomplished, the agencies are called on to give counseling service and to develop new living arrangement resources.

6. The Committee found that the agencies serving unwed mothers are responsive to the shifts in the needs for services and are adapting their services to meet the changed requirements presented by girls who are pregnant out of wedlock today.

7. White Shield Home is an example of an agency that is attempting to adapt its facilities and resources to the changing needs of unwed mothers seeking their services.

Prior to 1968 , White Shield's capacity was 46 . After a building program was completed, the facility at White Shield could accommodate 74 unwed mothers. In the past because of the pressure from numbers, those accepted at 
TRI-COUNTY COMMUNITY COUNCIL, continued

White Shield were discharged six days after the birth of the child. Again because of the pressure of numbers, White Shield did not follow the girls back into the community believing the efforts that took place while she was at White Shield were sufficient.

Faced with the changes in demand for services and particularly with under demand for residential care, White Shield Home has adapted its program. Currently White Shield Home offers care of prenatal nature to 34 unwed mothers. In a newly developed post-natal program it offers care to 16 mothers who have delivered and to their 16 infants. The post-natal program is designed for girls who wish to keep their child and permits White Shield to assist the mothers in learning about child care and child health, to offer supportive services while the mother is adjusting to her role as a parent, and to allow the mother to continue her education, pursue vocational training or go to work. White Shield has made available a building on the campus which was formerly used as a nurses' residence for child care for mothers in the postnatal program who must leave the campus for work. The residence is not yet licensed by the state so it is currently used on a cooperative basis as a baby sitting facility, with the mothers trading services.

Currently, White Shield has 40 girls in their prenatal program ( 4 over capacity) and 9 mothers and 9 children in their post-natal program. With this population and with the interest being shown by the community in both the pre- and post-natal programs, White Shield believes that they will no longer be faced with the financial problems incident to under occupancy.

In addition to services already mentioned, White Shield Home offers counseling, junior high and high school programs, and obstetrical services at E. Henry Wemme Memorial Hospital which is on the campus of White Shield. Costs of service averages $\$ 8.00$ per day for each mother in the prenatal program and $\$ 15.00$ per day for each mother-infant combination in the post-natal program. Hospital costs are additional averaging $\$ 60.00$ per day for the mother and $\$ 55.00$ per day for the infant.

8. The Committee was favorably impressed with White Shield's efforts and success in involving fathers in their counseling program. 
TRI-COUNTY COMMUNITY COUNCIL, continued

Unfortunately the Committee did not determine if other agencies serving unwed mothers are endeavoring, with equal success, in offering services to fathers.

9. The Committee learned that unwed mothers living at white Shield must attend religious services twice weekly and that in some instances this policy is resented by the mothers.

10. White Shield's general practice is to offer residential and other services to an unwed mother who considers the possibility of a therapeutic abortion. If the mother decides to have an abortion, she is discharged. In one instance however, a mother who had an abortion did return to residence at White Shield.

11. The agencies that serve unwed mothers support the adaptations in White Shield's program. These agencies believe that these services should continue to be offered the community and believe that they are of particular value to the younger unwed mothers. The agencies did not believe that White Shield should be the single alternative for residential care in this community or the only alternative for mothers who wish to keep their children.

12. The State Children's Services Division has recognized the services at White Shield Home and has made arrangements to pay for the full cost of care for part of the population at White Shield in both the prenatal and post-natal programs.

13. The Committee had the occasion to gather some impressions about i.tems that are incidental to its central purpose:

The Committee learned that although the policy of the Portland Public Schools is to allow girls who are pregnant to remain in school, there does seem to be informal pressures on pregnant girls to leave school during their pregnancy.

Because of its concern about the expense of hospital facilities on the campus at White Shield, the Committee looked into the demand for obstetrical services in Portland area hospitals and found that over the past several years there has been marked under-occupancy of obstetrical beds in local hospitals. This trend has been so marked that many hospitals routinely use "obstetrical" beds for non-obstetrical patients. 
TRI-COUNTY COMMUNITY COUNCIL, continued

The Committee learned that many agencies serving unwed mothers refer them to community hospitals for delivery without problem.

From the information gathered informally, the Committee understands that there is a great deal of pressure and over crowding of the hospital facilities where women choosing to do so, may have a therapeutic abortion .

The Committee believes that unwed mother service must be broadly defined and include the following elements: counseling of the unwed mother and father and the mother's and father's family, prenatal health care, continuation of the unwed mother's education, along with vocational training and career guidance, abortion counseling, child care and health training for the unwed mother and father, residential care for some during the prenatal and for others during the post-natal period for both mother and child, family planning services and financial assistance.

\section{CONCLUSIONS}

1. The agencies that have traditionally served unwed mothers are encouraged to continue adapting their programs to serve the changing needs of these mothers. Additionally, these agencies are asked to review their policies and practices, so that unwed fathers are involved in service and counseling programs.

2. The post-natal program for mothers and their infants at White Shield Home is a sound development responsive to the changing needs of unwed mothers.

3. The programs at White Shield appear to be suited for younger girls, those desiring confidentiality, and those who need to be away from their home community. White Shield should continue and develop methods of informing the appropriate publics of the full range of their services, so those needing it's services are attracted to White Shield.

4. White Shield should review it's polices and practices so that those seen as restrictive by the mothers, be modified wherever possible. 
TRI-COUNTY COMMUNITY COUNCIL, continued

5. In those instances where White Shield is serving an unwed mother who decides to have a therapeutic abortion, White Shield should insure that this mother is referred to an agency that will assist her with abortion counseling.

6. The Committee did not reach a conclusion concerning the curtailment of the use of the E. Henry Wemme Memorial Hospital, despite its concern about the costs involved and the availability of obstetrical beds elsewhere in the community. However, the Committee asks that White Shield fully review its use of the Hospital and consider both expanded uses of the present facility (for example, providing obstetrical services to married women) and alternative non-hospital uses of this facility.

7. The Tri-County Community Council should follow this study with a more complete field of service study which considers adoption services and services to unwed mothers including counseling both before and after therapeutic abortion.

COMMITTEE MEMBERS:

Mrs. Lucile M. Brunskill

Mrs. Rita Clinton

Dr. John M. Deeney

Mr. Harris Dusenbery

Rev. Eugene Ross

Mrs. Genevieve Thomas

February 25, 1972 


\section{APPENDIX G}

\section{The Salvation Army White Shield Home and E. Henry Wemme Maternity Hospital}

TELEPHONE $226.4053 \quad 2640$ N.W. ALEXANDRA AVENUE

P. D. BDX 10027

PORTLAND, OREGLN 97210

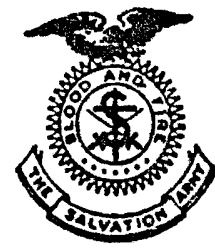

August 7, 1972

Foundation

Officer

Street Address

City, State, Zip Code

Dear

New programs and patterns of service at The Salvation Army White Shield Home and Hospital are establishing precedents which may become models for other facilities for unwed mothers and their children across the nation.

These accomplishments are ones that all civic-minded Portlanders can take pride in; and $I$ felt that you would want to know more about what concern, study, research and counsel have brought about at this institution which has been serving Oregon since 1896.

It was obvious to all involved in the White Shield operation that legalized abortions and a softening of society's harsh judgements of unwed mothers signaled a change in the services most needed. Confidentiality no longer was a crucial requirement of so many but the emotional, educational, vocational, medical and spiritual support which White Shield offers was needed as much as ever.

Most of the facilities at White Shield fitted needed programs and services, but equipment and staff to put them into operation constitutes an extraordinary expense. Hence our contacting a limited number of organizations for assistance. United Good Neighbors is aware of the request we are making.

On the basis of study and recommendations made by the Hospital Advisory Council Special Committee, services at White Shield have been expanded to provide three programs.

1. Pre-Natal Program for Unwed Expectant Mothers represents 45 percent of the Home Care Service. It includes room and board, residential program, professional casework and group counseling, 


\section{LETTER - DESCRIPTION OF PROGRAMS}

religious programs and counseling, medical care, educational and recreational programs. High School education is provided through affiliation with Portland Public School District \#1.

2. Post-Partum Continuing Program represents 5 percent of the Home Care Services. It is designed for the young mother who realizes a continued need for the supportive environment of White Shield following separation from her child. She receives help in working out and accomplishing specific goals for herself. It is a goal oriented program and similar to halfway house care.

3. Mother/Child Program represents 50 percent of the Home Care Services. This program is designed to give 24-hour care to the single, dependent mother with her child. In 1969, only 22 percent of the mothers kept their babies. In 1971, more than 60 percent kept their infants. This new service offers comprehensive, tangible help to both mother and child. It includes instruction in mothering, housekeeping, budgeting and other skills which will enable the mother to make a strong home for herself and her child. The mother sets goals for herself aimed toward adequacy and self-support as a head-of-the-household. Individual and group counseling is provided. Education, medical, religious and recreational programs are offered. The licensed Child Care Center is on the grounds.

This Child Care Center also is available to serve children of mothers living in the outside community. It is licensed for a capacity of 24 infants and/or toddlers at one time, meeting a critical need which is not met elsewhere. When the full capacity is not being used by children of mothers in the White Shield Mother/Child Program it is available to working mothers in the community.

The White Shield Home Care Program is licensed by the Children's Services Division of the Oregon Department of Human Resources. It has a capacity for 68 ( 52 women and 16 infants) in its residence program. 
LETTER - DESCRIPTION OF PROGRAMS, continued

The maternity hospital, also on the grounds is licensed by the State Department of Public Health for 12 maternity beds and 14 bassinets. 


\section{APPENDIX H}

\section{REPORT ON SERVICES AT WHITE SHIELD HOME \\ AND WEMME MATERNITY HOSPITAL \\ July 14, 1973}

The Salvation Army White Shield Home

\& E. Henry Wemme Maternity Hospital

2640 N.W. Alexandra Avenue

Portland, Oregon 97210

TO: Mr. Albert Bullier, Sr.

President

E. Henry Wemme Board of Trustees

Portland, Oregon

Report on Services at White Shield Home and Wemme Maternity

$$
\mathrm{Ju} \frac{\text { Hospital }}{\stackrel{14, \quad 1973}{\mathrm{y}}}
$$

\section{SERVICES NOW ON-GOING}

We are now operating a Residential Service for Pregnant

Unwed Women, with a full gamut of auxiliary services. This is the same type of care we have given for years in Portland and of which you are quite aware. The one change which required certification approval was to reduce the available. spaces from 74 to 36 .

A Residential Program for Unwed Mothers who have decided to keep their Infants, and whose goals indicate a need to them for our home services has been added. This is called the Infant-Maternal Program (IMP). It occupies the first floor of our residential facility and has a capacity for 16 mothers with 16 babies.

These two programs feed into the two services operated by the Salvation Army on the Wemme property. Those two programs are:

The Licensed Speciality Maternity Hospital and Out-Patient Clinic for the young women participating in our Pre-natal Program. These medical services are available to those who live in residence at White Shield Home and those who are a part of our service but live out of residence. We are 
REPORT ON SERVICES, continued

regularly transferring patients to Emanuel Hospital for delivery, unless it is an emergency situation or the doctor determines it is best for the patient to be delivered at Wemme Hospital. We have secured approval from the American Hospital Association for our Hospital for two more years, and we have had our license to continue to operate this Hospital in Multnomah County until June 30, 1974. At that time application for renewal is required. We are licensed as a 12 bed maternity hospital, and it is the only such speciality hospital in Oregon. The affiliation with Emanual is in the "signing" stages, having been duly executed on date that Emanual Hospital signs agreement.

The new program which has been developed and licensed and now is in operation on Wemme property is the Young Child Care Center. Its primary focus is to provide child care for the infants and toddlers of mothers in "IMP", but it has available spaces and extends care to people in the surrounding community. It is housed in what was the Nursing Staff Residence, and has a capacity to care for 24 infants and toddlers ranging from three weeks to 36 months. It now operates from $7 \mathrm{a.m}$. to $7 \mathrm{p.m}$., Monday thru Friday.

Portland School District \#1 operates a fully certified Junior Hi and High School under Special Education in our School and Chapel Building. It is open to enrollees in both our Pre-Natal and IMP Programs.

\section{SUMMARY OF SERVICE PERSPECTIVE:}

The Pre-Natal Program seems to have hit rock bottom and now shows an ever so slight indication of an upward trend. We believe the present program is sound and should be maintained as it is. The need for care, resulting from pregnancy out of wedlock has not diminished in the city or state. The utilization of residential care such as ours will be proven only by time and actual presentation of needs. Projections of service needs has always been difficult in this program.

The IMP and Child Care Center both seem to be meeting a definite need for now. Our ability to achieve the quality of care needed and to reach the objectives set, is steadily improving with experience; but they are very demanding services and we have a long ways to go to feel satisfied. The decision to develop and offer these two new services appears 
REPORT ON SERVICES, continued

to have been a right one, and we expect to continue at the task of upgrading and developing the quality of care in both programs.

The Hospital presents our biggest challenge right now. The need for hospital beds fluctuates with the Pre-Natal program and we are not using that building to anything near capacity. This year should be one of careful study and objective evaluations. We are trying a number of different methods to reduce operating costs, such as changing work loads for R.N., etc. It appears to me that a possible better service would be to reduce the maternity bed capacity to eight beds instead of twelve, and utilize that portion of the Hospital for an extended care area giving more preparatory experience for young women keeping their babies. Something like a "half-way house" section.

The methods for delivery of health care services in the community, and at Emanual Hospital in particular, should be decisive factors in how to use the facility. We see several modifications that might be much more relevant to needs and also compatible with the Wemme Trust interest, which will be considered and perhaps recommended within the next year. The majority of my thinking is now being occupied with this particular facet of service.

We are now renewing the Medical staff appointments for this year, and have the affiliation agreement with Emanual Hospital actually in the working out stages.

\section{FINANCIAL ASPECTS :}

At the present time we are in better condition than we have been in the last three years. We have survived the crisis. All our obligations are met to date and we are even having the joy of deciding what area should receive some additional benefits! 


\section{APPENDIX I}

THE MANAGEMENT TEAM APPROACH--AUGUST 27, 1973

To balance a canopy of service, The Salvation Army, a California corporation, has delegated responsibility for White Shield Home to an administrator who has, in turn, started delegating some of her responsibilities to administrative assistants and directors.

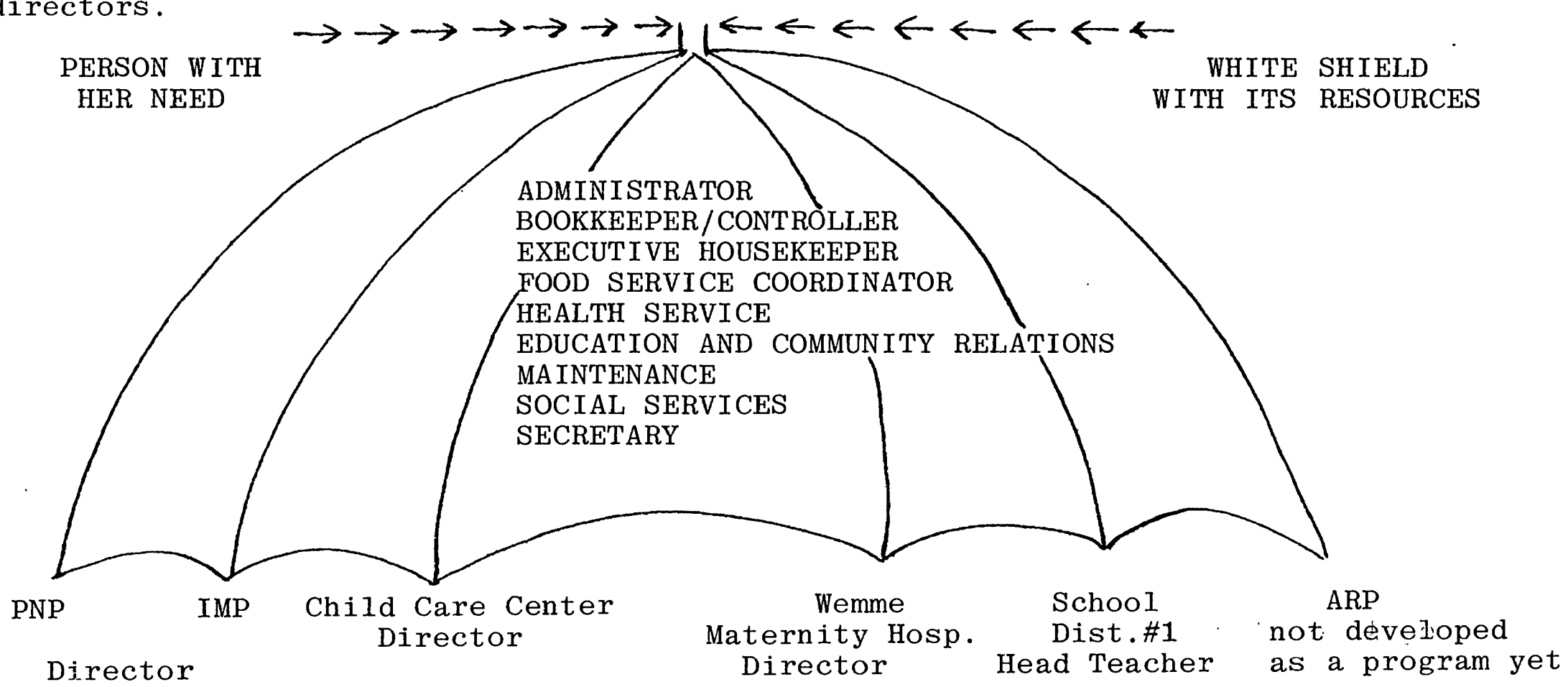




\section{APPENDIX J}

\section{AGE DISTRIBUTION BY DECADE}

1940 's :

Age
Below 16
$16-18$
$19-21$
Over 21

Raw Score

Percentage

1

8.3

$6 \quad 50.0$

325.0

Over 21

2

16.6

1950 's :

Age
Below 16
$16-18$
$19-21$
Over 21

$\underline{\text { Raw Score }}$

Percentage

2

16.6

6

50.0

3

25.0

1

8.3

1960 's :

Age
Below 16
$16-18$
$19-21$
Over 21

Raw Score

Percentage

2

16.6

4

33.3

3

25.0

3

25.0

1970 's :

Age
Below 16
$16-18$
$19-21$
Over 21

$\underline{\text { Raw Score }}$

Percentage

22.2

4

44.4

2

22.2

1

11.1 
PERCENTAGES FROM SINGLE PARENT HOMES BY DECADE

$1940^{\prime} \mathrm{s}$ :

Percentage

58.3

25.0

16.6
From single parent homes

From two parent homes

Information not given
Raw Score

7
3
2

Raw Score

5

7

$\underline{\text { Raw Score }}$

4

8

1970 's :

Percentage

$\underline{\text { Raw Score }}$

33.3

From single parent homes

66.6

From two parent homes

66.6

From single parent homes

From two parent homes

3

6 


\author{
APPENDIX L \\ PERCENTAGE RECEIVING STATE AID BY DECADE
}

$1940^{\prime} \mathrm{s}:$

Percentage

Raw Scores

33.3

50.0

16.6

Received state aid

4

Did not

6

Information not given

2

1950 's :

Percentage

$\underline{\text { Raw Scores }}$

91.6

8.3

Received state aid

Did not

11

1

$1960^{\prime} \mathrm{s}$ :

Percentage

Raw Scores

91.6

Received state aid

11

8.3

Information not given

1

$1970^{\prime} \mathrm{s}$ :

Percentage

$\underline{\text { Raw Scores }}$

66.6

Received state aid

6

33.3

Information not given

3 